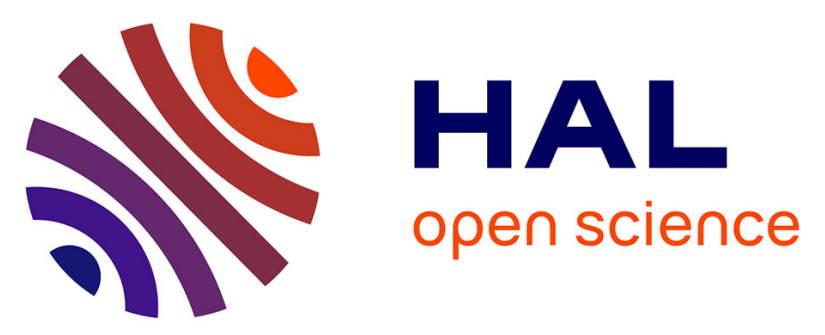

\title{
Water binding to FeIII hemes studied in a cooled ion trap: characterization of a strong 'weak' ligand
}

Mohammad Aarabi, Satchin Soorkia, Gilles Grégoire, Michel Broquier, Aurélien de La Lande, Benoît Soep, Reza Omidyan, Niloufar Shafizadeh

\section{- To cite this version:}

Mohammad Aarabi, Satchin Soorkia, Gilles Grégoire, Michel Broquier, Aurélien de La Lande, et al.. Water binding to FeIII hemes studied in a cooled ion trap: characterization of a strong 'weak' ligand. Physical Chemistry Chemical Physics, 2019, 21 (38), pp.21329 - 21340. 10.1039/c9cp03608c . hal-03007999

\section{HAL Id: hal-03007999 \\ https://hal.science/hal-03007999}

Submitted on 7 Dec 2020

HAL is a multi-disciplinary open access archive for the deposit and dissemination of scientific research documents, whether they are published or not. The documents may come from teaching and research institutions in France or abroad, or from public or private research centers.
L'archive ouverte pluridisciplinaire HAL, est destinée au dépôt et à la diffusion de documents scientifiques de niveau recherche, publiés ou non, émanant des établissements d'enseignement et de recherche français ou étrangers, des laboratoires publics ou privés. 


\title{
Water binding to $\mathrm{Fe}^{\mathrm{III}}$ Hemes studied in a cooled ion trap; characterization
}

\section{of a strong 'weak' ligand}

Mohammad Aarabi ${ }^{\mathrm{a}}$, Satchin Soorkia ${ }^{\mathrm{b}}$, Gilles Grégoire ${ }^{\mathrm{b}}$, Michel Broquier ${ }^{\mathrm{b}, \mathrm{c}}$, Aurélien de la Lande $^{\mathrm{d}}$, Benoît Soep ${ }^{\mathrm{e}}$, Reza Omidyan ${ }^{\mathrm{a}}$ and Niloufar Shafizadeh ${ }^{\mathrm{b}, *}$

${ }^{a}$ Department of Chemistry, University of Isfahan, 81746-73441 Isfahan, Iran

' ISMO, Université Paris-Sud, CNRS UMR 8214, bat 520, Université Paris-Sud 91405, Orsay Cedex, France

${ }^{c}$ Centre Laser de l'Université Paris-Sud (CLUPS/LUMAT), Univ. Paris-Sud, CNRS, IOGS, Université Paris-Saclay, F-91405 Orsay (France)

'Laboratoire de Chimie-Physique, Université Paris Sud, CNRS, UMR 8000. 15, rue Jean Perrin, 91405

Orsay Cedex, France.

${ }^{e}$ LIDYL, CEA, CNRS, Université Paris-Saclay, UMR 9222 CEA Saclay, F-91191 Gif-sur-Yvette,

\begin{abstract}
The interaction of a water molecule with ferric heme - iron protoporphyrin $\left(\left[\mathrm{PP} \mathrm{Fe}^{\mathrm{III}}\right]^{+}\right)$has been investigated in the gas phase, in an ion trap and studied theoretically by Density Functional Theory. It is found that the interaction of water with ferric heme leads to a stable $\left[\mathrm{PP}-\mathrm{Fe}^{\mathrm{III}}-\mathrm{H}_{2} \mathrm{O}\right]^{+}$complex in the intermediate spin state $(\mathrm{S}=3 / 2)$, in the same state as its unligated $\left[\mathrm{PP}-\mathrm{Fe}^{\mathrm{III}}\right]^{+}$homologue, without spin crossing during water attachment. Using the Van't Hoff equation, the reaction enthalpy for the formation of a $\mathrm{Fe}-\mathrm{OH}_{2}$ bond has been determined for [PP-Fe $\left.{ }^{\mathrm{III}}-\mathrm{H}_{2} \mathrm{O}\right]^{+}$and $[\mathrm{PP}-$ $\left.\mathrm{Fe}^{\mathrm{III}}-\left(\mathrm{H}_{2} \mathrm{O}\right)_{2}\right]^{+}$. The corrected binding energy for a single $\mathrm{Fe}-\mathrm{H}_{2} \mathrm{O}$ bond is $-12.2 \pm 0.6 \mathrm{kcal}^{\mathrm{mol}}{ }^{-1}$, while DFT calculations at the OPBE level yield $-11.7 \mathrm{kcal}_{\mathrm{mol}}{ }^{-1}$. The binding energy of the second ligation yielding a six coordinated $\mathrm{Fe}^{\mathrm{III}}$ atom is decreased with a bond energy of $-9 \pm 0.9 \mathrm{kcal}^{\mathrm{mol}}{ }^{-1}$, well reproduced by calculations as $-7.1 \mathrm{kcal}_{\mathrm{mol}}{ }^{-1}$. However, calculations reveal features of a weaker bond type, such as a rather long Fe-O bond with $2.28 \AA$ for the $\left[\mathrm{PP}-\mathrm{Fe}^{\mathrm{III}}-\mathrm{H}_{2} \mathrm{O}\right]^{+}$complex and the absence of spin change by complexation. Thus despite a strong bond with $\mathrm{H}_{2} \mathrm{O}$, the $\mathrm{Fe}^{\mathrm{III}}$ atom does not show through theoretical modelling, a strong acceptor character in its half filled $3 \mathrm{~d}_{\mathrm{z} 2}$ orbital. It is observed also that the binding properties of $\mathrm{H}_{2} \mathrm{O}$ to hemes seem strikingly specific to ferric heme and we have shown experimentally and theoretically, that the affinity of $\mathrm{H}_{2} \mathrm{O}$ for protonated heme $[\mathrm{H} \mathrm{PP}-\mathrm{Fe}]^{+}$, an intermediate between $\mathrm{Fe}^{\mathrm{III}}$ and $\mathrm{Fe}^{\mathrm{II}}$, is strongly reduced compared to that of ferric heme.
\end{abstract}




\section{1-Introduction}

Hemoproteins, which operate many functions in living organisms, such as molecule transport or oxydo-reduction reactions, function in aqueous media. Thus, the binding of water to their heme centers is an important factor influencing ligand fixation or their operation. More specifically, ferric hemoproteins ligate water that penetrates the globin protein pocket. In met-myoglobin ( $\mathrm{Fe}^{\mathrm{III}}$ myoglobin), a series of structural X-ray diffraction studies on various mutants, showed the tight bonding of a water molecule to the $\mathrm{Fe}$ atom ${ }^{1}$. Water forms a $\sigma$ bond with the $\mathrm{Fe}$ atom by interaction of the $\pi\left(b_{2}\right)$ lone pair of the oxygen atom with the $\mathrm{Fe}\left(3 \mathrm{~d}_{\mathrm{z} 2}\right)$ orbital. Within hemoproteins, this bonding combines also with a strong interaction of a water $\mathrm{H}$ atom with the distal histidine by hydrogen bonding ${ }^{1}$.

Therefore, strong ligands to ferric hemeproteins need to displace the water ligand to attach the Fe atom on heme. As an example, the attachment of NO that inactivates the catalase enzyme requires removing the $\mathrm{Fe}-\mathrm{OH}_{2}$ bond in aqueous media and the binding equilibria of $\mathrm{NO}$ to these proteins cannot be established in a straightforward manner. Indeed, flash photolysis ${ }^{2}$ studies of NO binding kinetics to met-myoglobin have shown that NO binding is stronger than that of water to metmyoglobin. There, water dissociation has been characterized with an activation barrier of $10 \pm 0.7 \mathrm{kcal}^{\mathrm{mol}}{ }^{-1}$. In order to explore the nature of water to ferric heme coordination in hemoproteins, it is essential to determine directly the interaction of ferric heme with water, in the absence of other ligands or solvating medium. This can achieved uniquely by thermodynamic measurements in the gas phase. Since the experiments of Dunbar et al. ${ }^{3}, \mathrm{we}^{4}$ and others ${ }^{5-7}$ have demonstrated that binding energy measurements in ion traps tackle the single bond interaction of a ligand with a metalloporphyrin. Indeed, we can address unambiguously the thermodynamic equilibrium with the $\mathrm{H}_{2} \mathrm{O}$ ligand of a selected species, here $\left[\mathrm{PP}-\mathrm{Fe}^{\mathrm{II}}\right]^{+}$, [PP-Fe $\left.{ }^{\mathrm{III}}-\left(\mathrm{H}_{2} \mathrm{O}\right)\right]^{+}$, [MI-PP$\left.\mathrm{Fe}^{\mathrm{III}}\right]^{+}$or $[\mathrm{H} \mathrm{PP}-\mathrm{Fe}]^{+}$, (where $\left[\mathrm{PP}-\mathrm{Fe}^{\mathrm{III}}\right]^{+}$stands for ferric heme - iron protoporphyrin, [H PP-Fe ${ }^{+}$ for protonated heme shown in Figure 6, and $\mathrm{MI}=$ methyl imidazole). Condensed phase measurements with iron porphyrins are difficult to achieve since, in solution with increasing concentrations, they tend to form $\mu$-hydroxo dimers ${ }^{8}$, such as $[(\mathrm{TPP}) \mathrm{Fe}-\mathrm{OH}-\mathrm{Fe}(\mathrm{TPP})]^{+}$.

The structures of aquamet-Myoglobin ${ }^{9}$ and of the $\left[\mathrm{Fe}^{\mathrm{III}} \mathrm{TPP}-\mathrm{H}_{2} \mathrm{O}\right]\left[\mathrm{CB}_{11} \mathrm{H}_{6} \mathrm{X}_{6}\right]^{8}$ axial complex have been characterized by X-ray crystallography. The ground state of $\left[\mathrm{Fe}^{\mathrm{III}} \mathrm{TPP}-\mathrm{H}_{2} \mathrm{O}\right]\left[\mathrm{CB}_{11} \mathrm{H}_{6} \mathrm{X}_{6}\right]$ 
corresponds to a nearly pure $S=3 / 2$ intermediate spin state from the NMR shift of $\beta$ pyrrole protons. Using the magnetochemical ranking ${ }^{8}$ that analyses the $S=5 / 2,3 / 2$ mixing through $\beta$ pyrrole proton NMR displacement, $\mathrm{H}_{2} \mathrm{O}$ is a weak axial ligand and the intermediate spin is confirmed by calculations for the ferric porphyrin ${ }^{10}$. The calculation of the binding energy of water is more difficult and leads to different values for the unsubstituted $\mathrm{Fe}^{\mathrm{III}}$ porphin: $-14.45 \mathrm{kcal}^{\mathrm{mol}}{ }^{-1}$ $(\mathrm{OPBE} / \mathrm{L} a \mathrm{~N} / 2 \mathrm{~d} z)$ and $-23.15 \mathrm{kcal} \mathrm{mol}^{-1}(\mathrm{~B} 3 \mathrm{LYP} / \mathrm{LaN} / 2 \mathrm{dz})$ for Renger et al. ${ }^{10}$ or $-13.9 \mathrm{kcal}^{\mathrm{mol}}{ }^{-1}$ (OPBE) and -6.9 kcal.mol ${ }^{-1}(\mathrm{~B} 3 \mathrm{LYP} / 6-311+\mathrm{G}(\mathrm{d}, \mathrm{p}))$ for Durrant ${ }^{11}$. The same calculations applied to the full ferric heme ${ }^{11}$ yield -11.6 (OPBE) and -3.6 (B3LYP) kcal.mol-1. These discrepancies show the importance of the comparison with direct experimental measurements, which can be achieved in a low pressure temperature controlled ion trap using the van't Hoff equation. Experimentally, the van't Hoff equation relates directly the temperature variations of the equilibrium constant between complexed and free heme with the enthalpy of complexation. This enthalpy can be extrapolated to $0 \mathrm{~K}$ providing the binding energy of the ion complex under study.

We present here a precise measurement of the $\left[\mathrm{PP}-\mathrm{Fe}^{\mathrm{III}}-\mathrm{H}_{2} \mathrm{O}\right]^{+}$and $\left[\mathrm{PP}-\mathrm{Fe}^{\mathrm{III}}-\left(\mathrm{H}_{2} \mathrm{O}\right)_{2}\right]^{+}$bond energies and compare the values with detailed DFT calculations investigating the structures, the energies and the electronic distribution within the Fe-O bond. Action spectra of the [PP$\left.\mathrm{Fe}^{\mathrm{III}}-\mathrm{H}_{2} \mathrm{O}\right]^{+}$complex reveal a structure in good agreement with calculations with an intermediate spin complex $S=3 / 2$. Furthermore, we find that the strong binding energy of a water molecule is specific to the fifth coordination of ferric heme, by comparing the affinity of protonated heme $[\mathrm{H}$ PP-Fe $]^{+}$(of mixed ferrous/ferric character) and that of ferric heme with $\mathrm{H}_{2} \mathrm{O}$.

\section{2-Experimental Setup}

The experimental setup has been described in details previously ${ }^{4,12}$. The setup is composed of three parts: an electrospray ionization source (ESI), a quadrupole ion trap (QIT, Jordan ToF Inc.) and a linear time-of-flight mass spectrometer (TOF). Hemin (Sigma-Aldrich) is dissolved in methanol, at a concentration of $\sim 100 \mu \mathrm{M}$. Protonated Heme $\left[\mathrm{H} \mathrm{PP}-\mathrm{Fe}^{\mathrm{II}}\right]^{+}$is obtained from in-source collision induced dissociation of the microenzyme Microperoxydase 11 in the chamber following electrospray ${ }^{13}$. This process leads to a partial transformation into protonated heme and ferric heme, 
in ratios that can be detected by mass spectrometry and adjusted by the collision energy in the high pressure region of the ESI source. Protonated heme has been characterized with the fixation of a proton on the vinyl $\mathrm{C}=\mathrm{C}$ bond in $\mathrm{C} 7$ of Fe prototporhyrin $\mathrm{IX}^{14}$, represented in Figure 6c.

At the exit of the skimmer, ions are stored in an octopole trap for $\sim 100 \mathrm{~ms}$. They are extracted by applying a negative voltage pulse and are further accelerated by a second pulsed voltage, applied just after the exit electrode. This time sequence produces ion packets. The ions are driven by a couple of electrostatic lenses toward the QIT, biased at $\sim 200 \mathrm{~V}$, which matches the energy of the incoming ions. A mass gate placed before the entrance of the QIT allows the selection of the parent ion. The QIT is cooled by a compressed helium cryostat at $\sim 10 \mathrm{~K}$ (CH-204S, Sumitomo). The temperature of the trap can be precisely monitored over the $10-310 \mathrm{~K}$ temperature range by a cartridge heater and a couple of temperature sensors interfaced to a temperature controller (Lake Shore model 335).

The ions are trapped and thermalized through collisions with the helium buffer gas, which is injected by a pulsed valve 1-2 ms before the ions enter the trap. The photodissociation laser for excitation spectra, is triggered after a variable storage delay, in the $40-80 \mathrm{~ms}$ time range. Ions are then synchronously extracted to a linear TOF mass spectrometer and detected on a microchannel plate detector (Z-Gap MCP, Jordan ToF Inc.). The one-color spectrum of the [PP-Fe ${ }^{\mathrm{III}}-$ ligand $]^{+}$ ions is obtained by scanning the laser frequency and recording the signal of the fragment $\left[\mathrm{PP}-\mathrm{Fe}^{\mathrm{III}}\right]^{+}$ ion.

The helium water mixtures: water vapor is premixed with helium prior to its introduction. Helium is flowed at 2 bar over a water vessel at $20^{\circ} \mathrm{C}$ providing a $\sim 20$ mbar maximum partial pressure. This ensures a maximum $1 \%$ concentration of water in the mixture, which accords with the necessary concentrations to achieve - more than one average collision of water with heme in the collision chamber per $80 \mathrm{~ms}$, the duration of the preparation of the equilibrium with its water complex. The water-helium mixture is directed by a small tubing from the general valve into the cold ion trap where thermalization of the gas mixture takes place through collisions with its walls. There, the local transient pressure never exceeds $10^{-2} \mathrm{mbar}$, therefore the local water vapor pressure amounts to $10^{-4} \mathrm{mbar}$ at maximum, which corresponds to a solid-vapor equilibrium temperature of $\approx 180 \mathrm{~K}^{15}$. This sets the minimum temperature of a linear van't Hoff cycle, since below this 
temperature, the $\mathrm{H}_{2} \mathrm{O}$ pressure will no longer be controlled by the pumping speed but will be partially decreased by condensation of $\mathrm{H}_{2} \mathrm{O}$ molecules on its walls, as temperature is decreased. We use pressures at the highest values (total corrected time averaged value of $\sim 2.10^{-5} \mathrm{mbar}$ ) to reach the largest number of collisions and maintain the temperature dependent equilibria at the highest values. Typically equal concentrations between $\left[\mathrm{PP}-\mathrm{Fe}^{\mathrm{III}}-\mathrm{H}_{2} \mathrm{O}\right]^{+}$and $\left[\mathrm{PP}-\mathrm{Fe}^{\mathrm{III}}\right]^{+}$is reached in the $270-240 \mathrm{~K}$ domain at a value labeled as $\mathrm{T}_{1}$. We shall be plotting $\operatorname{Ln}\left({ }_{\left[\mathrm{PP}-\mathrm{Fe}^{\mathrm{III}}-\mathrm{H}_{2} \mathrm{O}\right]^{+}} / \mathrm{I}_{\left[\mathrm{PP}-\mathrm{Fe}^{\mathrm{III}}\right]^{+}}\right)=\operatorname{Ln}\left(\mathrm{K}_{\mathrm{p}}(\mathrm{T})^{*} \mathrm{p}\right)$, therefore this plot rises linearly with the Logarithm (base e) of the water vapor pressure, $(\operatorname{Ln}(p)) . \mathrm{I}_{[\mathrm{x}]}$ represents the surface of the relevant mass peaks of species $\mathrm{X}$, since there is a mass distribution over 5 isotopologues for heme compounds of 0.6 amu width.

We have operated in 3 different regimes, depending upon the desired equilibrium: i) [PP$\left.\mathrm{Fe}^{\mathrm{III}}-\mathrm{H}_{2} \mathrm{O}\right]^{+} /\left[\mathrm{PP}_{-} \mathrm{Fe}^{\mathrm{III}}\right]^{+}, 10^{-5}$ mbar helium average pressure to achieve the formation of the complex but minimize $\left[\mathrm{PP}-\mathrm{Fe}^{\mathrm{III}}-\left(\mathrm{H}_{2} \mathrm{O}\right)_{2}\right]^{+}$. The latter is obtained with ii) $2.10^{-5} \mathrm{mbar}$ for $\left[\mathrm{PP}-\mathrm{Fe}^{\mathrm{III}}-\left(\mathrm{H}_{2} \mathrm{O}\right)_{2}\right]^{+}$ / $\left[\mathrm{PP}-\mathrm{Fe}^{\mathrm{III}}-\mathrm{H}_{2} \mathrm{O}\right]^{+}$since this requires the prior formation of the $\left[\mathrm{PP}-\mathrm{Fe}^{\mathrm{III}}-\left(\mathrm{H}_{2} \mathrm{O}\right)\right]^{+}$complex. iii) For the equilibrium between protonated heme $[\mathrm{H} \mathrm{PP}-\mathrm{Fe}]^{+}$and $\mathrm{H}_{2} \mathrm{O}$, i.e. $\left[\mathrm{H} \mathrm{PP}-\mathrm{Fe}-\mathrm{H}_{2} \mathrm{O}\right]^{+} /[\mathrm{H} \mathrm{PP}-\mathrm{Fe}]^{+}$, different conditions are needed since a $\sim 1 / 1$ mixture of $\left[\mathrm{PP}-\mathrm{Fe}^{\mathrm{IIII}}\right]^{+}$and $[\mathrm{H} \mathrm{PP}-\mathrm{Fe}]^{+}$is formed, differing by $1 \mathrm{amu}$. Then mass resolution is essential to discriminate $\left[\mathrm{PP}-\mathrm{Fe}^{\mathrm{III}}\right]^{+}$from $[\mathrm{H} \mathrm{PP}-\mathrm{Fe}]^{+}$ and this has required lower average pressures $\left(\sim 0.510^{-5} \mathrm{mbar}\right)$. Low temperatures typically (170$150 \mathrm{~K})$ are thus required to compensate the pressure decrease and the lower affinity of $[\mathrm{H} \mathrm{PP}-\mathrm{Fe}]^{+}$ for $\mathrm{H}_{2} \mathrm{O}$ as observed below.

Action spectra were recorded with a tunable OPO laser (mode-locked picosecond Nd:YAG laser EKSPLA-SL300 LT-02300 pumping an optical parametric amplifier (EKSPLA-PG411) to obtain tunable visible light. The tunable laser $\left(500 \mu \mathrm{J} /\right.$ pulse over $5 \mathrm{~mm}^{2}$ and $8 \mathrm{~cm}^{-1}$ resolution) was scanned through the absorption bands of the heme complex while recording the intensity of the free heme ions. As the depletion of complexed ions is important a normalization by the total number of ions (complexed + uncomplexed) is accomplished. The spectra are recorded in complete complexation conditions. 


\section{3-Computational details:}

In this work, the geometry optimizations for the heme-Fe ${ }^{\mathrm{III}}$ systems were performed using the deMon $2 \mathrm{k}^{16}$ suite of programs in the framework of Auxiliary DFT (A-DFT).

We used the OPTX exchange functional proposed by Cohen and Handy, coupled to the PerdewBecke-Ernzerhof (PBE) correlation functional (OPBE). A double- $\zeta$ valence polarization basis set calibrated for Generalized Gradient Approximation (GGA) functionals has been used (DZVPGGA) on all atoms. All calculations have been performed within the unrestricted Kohn-Sham (UKS) formalism. Auxiliary electron densities were expanded with the automatically generated GEN-A2 auxiliary basis set on $\mathrm{C}, \mathrm{H}$ and the larger GEN-A2* basis set (including functions with $\mathrm{f}$ and $\mathrm{g}$ angular momentum) on the $\mathrm{Fe}, \mathrm{O}$ and $\mathrm{N}$ atoms involved in interaction. Therefore, the choice of the more flexible GEN-A2* auxiliary basis set for Fe, $\mathrm{O}$ and $\mathrm{N}$ atoms permits an accurate description of metal-ligand bonding. Dispersion effect corrections ${ }^{17}$ were also considered by an empirical expression during geometry optimizations. To integrate the $\mathrm{XC}$ energy and potential, an adaptive grid of fine accuracy has been used $\left(10^{-6} \mathrm{Ha}\right)$. SCF iterations and geometry optimizations were also performed with convergence criteria of $10^{-7} \mathrm{Ha}$ and $10^{-5} \mathrm{Ha}^{-B_{0 h}{ }^{-1}}$ respectively (Ha stands for Hartree).

We performed single point calculations on the OPBE/DZVP-GGA optimized structures using large cc-pVTZ (for $\mathrm{C}$ and $\mathrm{H}$ ) and aug-cc-pVTZ basis sets (for Fe, $\mathrm{N}$ and $\mathrm{O}$ atoms) to determine the binding energy of water to heme systems. Binding energies were also corrected for the zero-point vibrational energy (ZPE), as well as for the long-range dispersion by considering a semi-empirical approach developed by Grimme (GD3) with Becke-Johnson damping factors (GD3BJ) ${ }^{17}$ to OPBE functional. The frequency analysis confirms that the considered structures are minima, owing to all the real vibrational frequency modes. It should be noted that for most of the studied complexes of this work, the calculated $\left\langle\mathrm{S}^{2}\right\rangle$ values were in excellent agreement with the theoretically expected values for the high-spin and intermediate-spin states except for some low-spin complexes for which an approximate spin projection correction technique was applied ${ }^{18}$ as described in ESI.

On the basis of the OPBE/DZVP-GGA optimized geometries, we have also determined a full analysis of topological parameters based on the Quantum Theory of Atoms in Molecules ${ }^{19}$ 
(QTAIM) as well as the Electron Localization Function ${ }^{20}$ (ELF) to study the nature of [PP$\left.\mathrm{Fe}^{\mathrm{III}}-\mathrm{H}_{2} \mathrm{O}\right]^{+}$bonding. The optimized geometries were employed to obtain suitable wave function files using the deMon2k software based on which the AIM and ELF calculations were performed using AIMAll ${ }^{21}$ and TopMoD programs ${ }^{22}$ respectively. The spin density values were also determined from the population analysis of the DFT electronic densities based on the iterative Hirshfeld scheme ${ }^{23}$ (HI) as implemented in deMon2k. Moreover, the Turbomole (version 6.3) program suite ${ }^{24}$ has been employed for the determination of electronic transition energies and oscillator strengths of the considered systems at the TD-DFT/B3LYP level using cc-pVDZ and TZVP basis sets for $(\mathrm{C}, \mathrm{H}, \mathrm{N}, \mathrm{O})$ and Fe respectively.

In order to determine the nature of the interaction between the iron atom and the oxygen atom of water in the ligation of ferric heme, we have used the Bader Quantum Theory of Atoms in Molecules (QTAIM) approach based on the analysis of the electron density $\rho(r)$ along the bond under scrutiny. This allows with the determination of the Laplacian of the density $\nabla^{2} \rho_{B C P}$, the electronic kinetic energy density $\left(G_{\mathrm{BCP}}\right)$, and the energy density $H_{B C P}$, a characterization of the nature of the bond at the critical point (BCP) as follows.

The line of the greatest electron density connecting the two atoms is named Atomic Interaction Line (AIL ) and the point which corresponds to the extremum of the electron density within this line (AIL) is the Bond Critical Point (BCP). The sign of the Laplacian of the electron density at $\mathrm{BCP}, \nabla^{2} \rho(B P C)$ determines an accumulation (maximum) of charge density or a depletion (minimum) in the region of atom-atom interaction. For a covalent interaction there is a concentration of the electron charge at the $\mathrm{BCP}$ and hence the Laplacian of the electron density is negative $\nabla^{2} \rho(B P C)<0$. On the other hand, with $\nabla^{2} \rho(B P C)>0$ a depletion of electron charge indicates an ionic or a non covalent interaction. In this way, some non covalent bonds have been well typified. ${ }^{19,25,26}$ 


\section{4-Results}

\section{4-1- Experimental results}

\section{4-1-1- Penta- and hexa-coordination of water to ferric Heme}

Water vapor easily attaches ferric heme with a total pressure of $1.10^{-5} \mathrm{mbar}$, with a ratio of complexed to free ferric heme of 12 at $232 \mathrm{~K}$ and the single ligation of water to ferric heme is represented in Figure 1a. Between 300 and $220 \mathrm{~K}$ and $10^{-5}$ mbar total pressure, no bi-ligated complex with water was detected, showing a lower affinity for the second complexation. Otherwise, once the first complexation is completed, a collision of $\left[\mathrm{PP}-\mathrm{Fe}^{\mathrm{III}}-\mathrm{H}_{2} \mathrm{O}\right]^{+}$with water would lead to the formation of $\left[\mathrm{PP}-\mathrm{Fe}^{\mathrm{III}}-\left(\mathrm{H}_{2} \mathrm{O}\right)_{2}\right]^{+}$.

The van't Hoff equation, $\frac{d}{d T} \operatorname{Ln}\left(K_{P}(T)\right)={ }^{\Delta_{r} H} / R T^{2}$ determines the slope $-\Delta_{r} H / R$ of the variation of $\operatorname{Ln} K_{P}(T)$ the association constant, as a function of the inverse temperature $1 / \mathrm{T}$. Thus, the ratio of the ion intensities, $\operatorname{Ln}\left({ }^{\mathrm{I}}\left[\mathrm{PP}-\mathrm{Fe}^{\mathrm{III}}-\mathrm{H}_{2} \mathrm{O}\right]^{+} / \mathrm{I}_{\left[\mathrm{PP}-\mathrm{Fe}^{\mathrm{III}}\right]^{+}}\right)$is traced here as a function of the inverse temperature $1 / \mathrm{T}$. It is found linear over the whole temperature range. The absolute value of the binding enthalpy $\left|\Delta_{\mathrm{r}} \mathrm{H}\right|$ can be obtained from the slope of the plot in Figure 1a, as $4500 \pm 220 \mathrm{~cm}^{-1}$. This value can be extrapolated at $0 \mathrm{~K}^{4}$ to $4250 \pm 210 \mathrm{~cm}^{-1}\left(12.2 \pm 0.6 \mathrm{kcal}^{-\mathrm{mol}^{-1}}\right)$ to derive the absolute value of the binding energy (hereafter labeled as binding), by taking into account the kinetic energy of $\mathrm{H}_{2} \mathrm{O}$ at $260 \mathrm{~K}(3 / 2 \mathrm{kT}$, k=Boltzmann constant), the average temperature in the explored range.

It is possible to derive a correlation between two similar equilibria by comparing the equal intensities of the heme complex and that of the free heme. Equal ion intensities of heme and its complex are obtained at $T_{1}$, the crossing with the abscissae of the van't Hoff plot, as in Figure 1b,

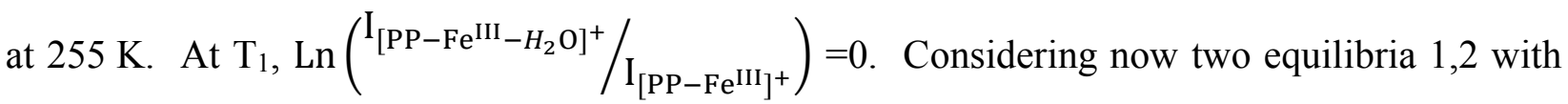
two similar entropy changes by ligation $\Delta \mathrm{S}$, one obtains at the crossing temperatures $\mathrm{T}_{1,2}$ : $-\Delta_{r} H_{\{1,2\}} / R T_{1,2}+\operatorname{Ln}(\mathrm{p})+\mathrm{C}_{1,2}=0[1]$. Then, assuming $\mathrm{C}_{1} \approx \mathrm{C}_{2} \quad$ ( similar $\Delta \mathrm{S}$ for the two equilibria) and the same pressure, one obtains $\Delta_{r} H_{1} / T_{1} \sim \Delta_{r} H_{2} / T_{2} \quad$ [2] by combining the 
equations for $T_{1}$ and $T_{2}$. This relation allows a correlation of the $\Delta_{\mathrm{r}} \mathrm{H}_{1,2}$ of the two equilibria through $\mathrm{T}_{1,2}$.
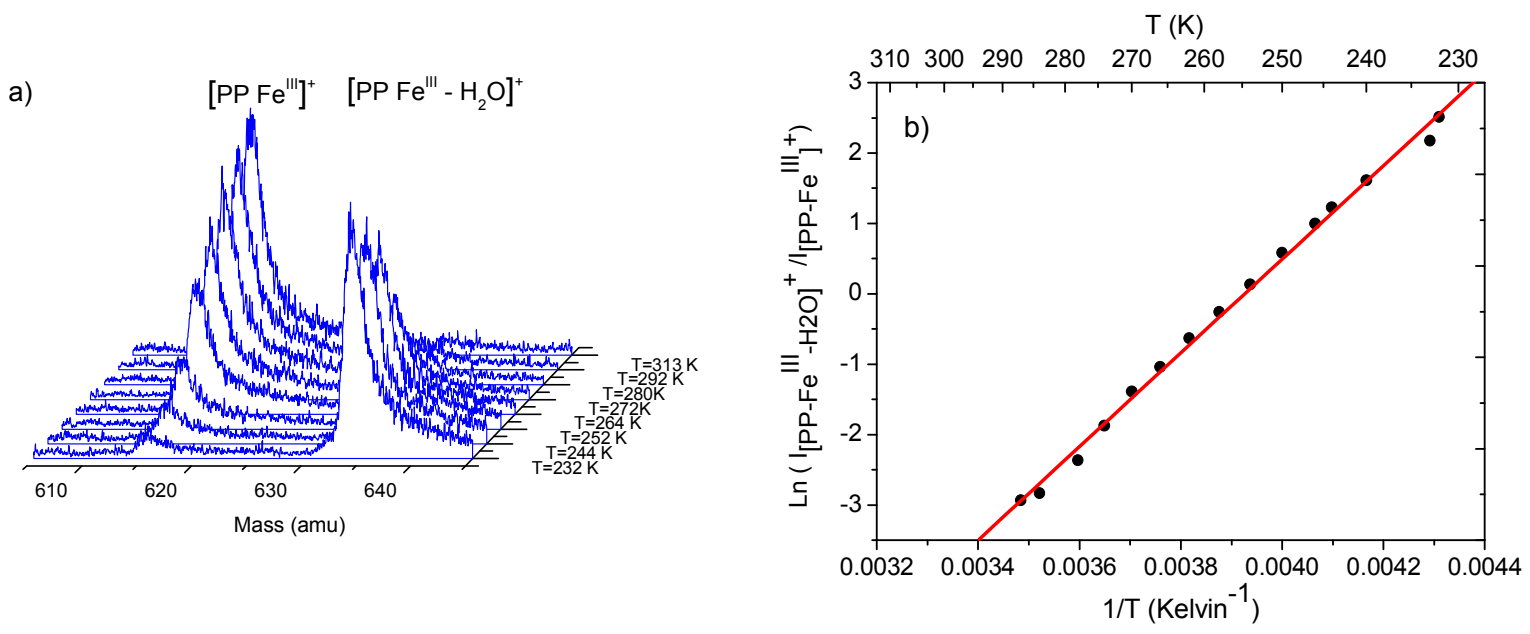

Figure 1: a)Mass spectra showing the evolution between $\left[\mathrm{PP}-\mathrm{Fe}^{I I I}-\mathrm{H}_{2} \mathrm{O}\right]^{+}$and $\left[\mathrm{PP}-\mathrm{Fe} e^{I I I}\right]^{+}$as a function of temperature between 290 and $230 \mathrm{~K}$; b) Van't Hoff plot of the $\left[\mathrm{PP}-\mathrm{Fe}^{\mathrm{III}}-\mathrm{H}_{2} \mathrm{O}\right]^{+} /\left[\mathrm{PP}-\mathrm{Fe}^{\mathrm{III}}\right]^{+}$equilibrium in the ion trap. Fitting slope $* R=4500 \mathrm{~cm}^{-1}$.

\section{Bi-ligated water complexes}

The formation of doubly ligated $\left[\mathrm{PP}-\mathrm{Fe}^{\mathrm{III}}-\left(\mathrm{H}_{2} \mathrm{O}\right)_{2}\right]^{+}$can be observed in Figure 2a, through its equilibrium with $\left[\mathrm{PP}-\mathrm{Fe}^{\mathrm{III}}-\mathrm{H}_{2} \mathrm{O}\right]^{+}$. More severe conditions are employed, a higher $\mathrm{H}_{2} \mathrm{O}$ number density, obtained with $2.10^{-5}$ mbar total pressure and at equilibrium temperatures below $220 \mathrm{~K}$. Then, the van't Hoff slope (Figure $2 \mathrm{~b}$ ) is $3350 \pm 300 \mathrm{~cm}^{-1}$, yielding a binding of $3140 \pm 310 \mathrm{~cm}^{-1}$ $\left(9 \pm 0.9 \mathrm{kcal} . \mathrm{mol}^{-1}\right)$ after kinetic energy correction. This value of the energy of this sixth coordination is notably smaller than that of the fifth. 

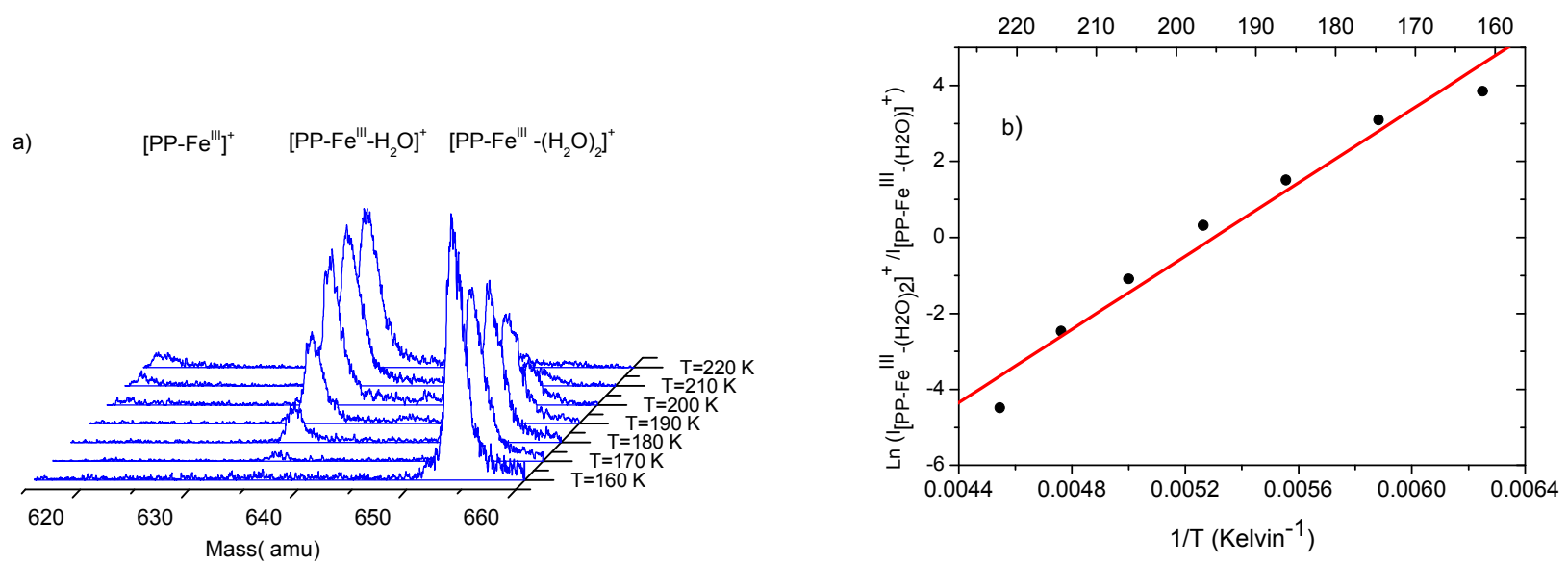

Figure 2: a)Mass spectra showing the evolution between $\left[\mathrm{PP}-\mathrm{Fe} e^{I I I}-\left(\mathrm{H}_{2} \mathrm{O}\right)_{2}\right]^{+}$and $\left[\mathrm{PP}-\mathrm{Fe} e^{\mathrm{III}}-\mathrm{H}_{2} \mathrm{O}\right]^{+}$as a function of temperature between 220 and $150 \mathrm{~K}$ at $2.10^{-5}$ mbar total pressure; b) Van't Hoff plot of the equilibrium of doubly ligated, versus simply ligated species $\left[\mathrm{PP}-\mathrm{Fe}^{\mathrm{III}}-\left(\mathrm{H}_{2} \mathrm{O}\right)_{2}\right]^{+} /\left[\mathrm{PP}-\mathrm{Fe}^{\mathrm{III}}-\mathrm{H}_{2} \mathrm{O}\right]^{+}$, fitting slope $R=3350 \mathrm{~cm}^{-1}$.

Water ligation to $\left[M I-P P-F e^{I I I}\right]^{+}$

When penta-coordinated protoporphyrin with methylimidazole, [MI-PP-Fe $\left.{ }^{\mathrm{III}}\right]^{+}$is cooled with an helium water mixture, the sixth coordinated complex $\left[\mathrm{MI}-\mathrm{PP}-\mathrm{Fe}^{\mathrm{III}}-\mathrm{H}_{2} \mathrm{O}\right]^{+}$is formed in extreme conditions at $155 \mathrm{~K}$, where the equilibrium water pressure has decreased below $10^{-6} \mathrm{mbar}$, as shown in figure S0 in ESI. Thus tracing a Van't Hoff plot is not realistic. However, in the same pressure conditions, this sixth coordination of $\mathrm{H}_{2} \mathrm{O}$ to [MI-PP-Fe $\left.{ }^{\mathrm{III}}\right]^{+}$can be correlated with the equilibrium of $\left[\mathrm{H}_{2} \mathrm{O}-\mathrm{PP}-\mathrm{Fe}^{\mathrm{III}}-\mathrm{H}_{2} \mathrm{O}\right]^{+} /\left[\mathrm{H}_{2} \mathrm{O}-\mathrm{PP}-\mathrm{Fe}^{\mathrm{IIII}}\right]^{+}+\mathrm{H}_{2} \mathrm{O}$ at $\mathrm{T}_{1}=195 \mathrm{~K}$ in Figure $2 \mathrm{~b}$, with $\left|\Delta_{\mathrm{r}} \mathrm{H}\right|=\left(9 \pm 0.9 \mathrm{kcal}^{\mathrm{mol}}{ }^{-1}\right)$. If $I_{\left[\mathrm{MI}-\mathrm{PP}-\mathrm{Fe}^{\mathrm{III}}-\mathrm{H}_{2} \mathrm{O}\right]^{+}}$would equal $I_{\left[\mathrm{MI}-\mathrm{PP}-\mathrm{Fe}^{\mathrm{III}}\right]^{+}}$at the temperature of $155 \mathrm{~K}$ in the same experimental conditions, using relation [2] would yield a binding of $\sim 9^{*} 155 / 195=7.1 \mathrm{kcal}^{\mathrm{mole}}{ }^{-1}$. Indeed, as represented in Fig S0 of ESI, the ratio of [MI-PP-Fe ${ }^{\mathrm{III}-}$ $\left.\mathrm{H}_{2} \mathrm{O}\right]^{+}$, to [MI-PP-Fe $\left.\mathrm{Fe}^{\mathrm{III}}\right]^{+}$is $\approx 1 / 20$ at $155 \mathrm{~K}$. Taking into account the vapor pressure reduction at 155 $\mathrm{K}$ with respect to the $180 \mathrm{~K}$ limit can increase this ratio to 1/1.Thus, the $\mathrm{Fe}-\mathrm{H}_{2} \mathrm{O}$ binding of [MIPP- $\left.\mathrm{Fe}^{\mathrm{III}-} \mathrm{H}_{2} \mathrm{O}\right]^{+}$, in the presence of MI should be lower than $\sim 7.1 \mathrm{kcal}^{\mathrm{mol}} \mathrm{l}^{-1}$. The presence of 
Methylimidazole in $5^{\text {th }}$ coordination of ferric heme has diminished strongly the $\mathrm{Fe}^{\mathrm{III}}$-water binding, as it is the case for ligands such as $\mathrm{O}_{2}$ and $\left.\mathrm{CO}\right)^{27}$.

\section{4-1-2 Specificity of the ligation of water to ferric heme}

It can be shown that ligation of water is specific to ferric heme by comparing its ligation to water with that of protonated heme. Protonated heme is intermediate between ferric and ferrous heme, thus bears some of its properties ${ }^{14,28}$ since protonation occurs at the periphery of the heme cycle and leaves a $\mathrm{Fe}^{\mathrm{II}} / \mathrm{Fe}^{\mathrm{III}}$ intermediate core. Indeed, when using a mixture of ferric heme and protonated heme as in reference ${ }^{13}$, we obtain a strikingly different affinity of $\mathrm{H}_{2} \mathrm{O}$ for ferric and protonated hemes. In presence of a mixture of ferric heme and protonated heme, one obtains in pure helium containing water at $155 \mathrm{~K}$, the mass spectrum shown in Figure 3. This has the advantage of comparing the affinity of ferric heme and protonated heme with $\mathrm{H}_{2} \mathrm{O}$ in the same experimental conditions.

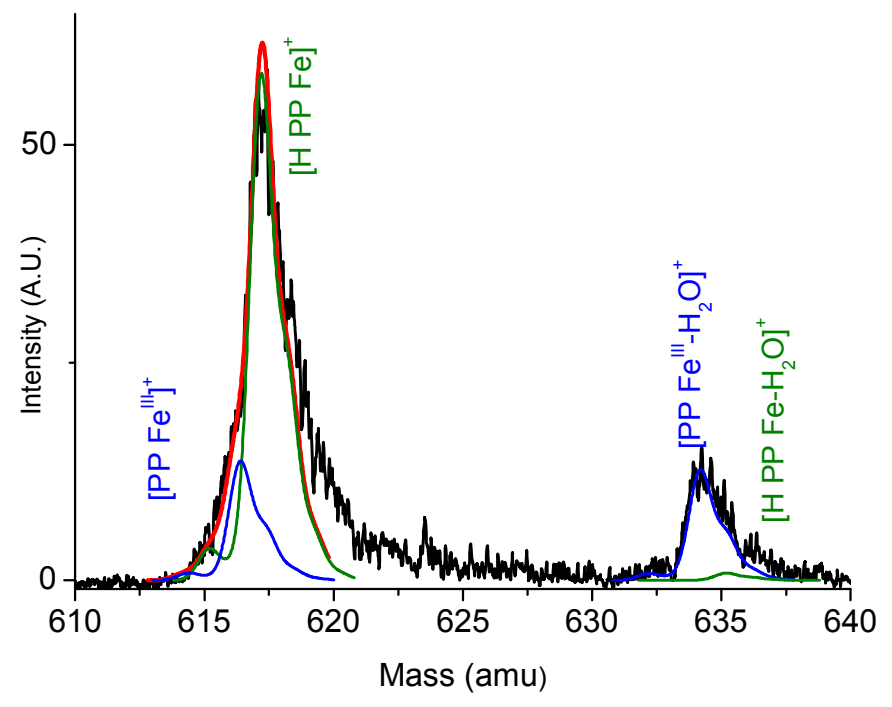

Figure 3: Black, mass spectrum obtained at 155 K for a mixture of ferric heme and protonated heme around $m=616$ amu and their 1:1 water complexes at $\sim 634$ amu. Using the isotope distribution of $\left[P P-F e^{I I I}\right]^{+}$and of $[\mathrm{HPP}-\mathrm{Fe}]^{+}$, the mass spectrum is deconvoluted into the contributions of ferric and protonated components, respectively in blue and green, while the fitting sum spectrum is in red. 
The mass spectrum in Figure 3 shows a separation of $17 \mathrm{amu}$ between the main peaks, free and complexed, showing that they belong to protonated and non protonated species. The spectrum is fitted with a superposition of the isotopic distributions of free and complexed ferric heme [PP$\left.\mathrm{Fe}^{\mathrm{III}}\right]^{+}$(blue) or those of protonated heme $[\mathrm{H} \mathrm{PP}-\mathrm{Fe}]^{+}$(green) with a convolution width of $1 \mathrm{amu}$ (full width half maximum, Gaussian), using a least square fitting routine. The fit is good, however for masses 620-625 amu, an impurity is contributing to the mass distribution of the free systems. Two other equivalent fits have been traced for $\mathrm{T}=189$ and $160 \mathrm{~K}$ in figure S1 of ESI.

While the ratio of water complexed to free ferric heme is 1 in Figure 3 ( $T=155 \mathrm{~K})$, that of water complexed to free protonated heme is less than $0.75 / 57$, as one sees in Figure 3 only a negligible contribution of protonated heme to the ligated species in green. This shows in the same temperature and pressure conditions a lower affinity of protonated heme for water present in the same concentration. The temperature can be varied for this mixture and a plot similar to a van't Hoff one can be traced in Figure 4 for both ferric heme and protonated heme. It shows in two plots, in blue for $\left.{ }^{[P P}-\mathrm{Fe}^{I I I}-\mathrm{H}_{2} \mathrm{O}\right]^{+} /\left[\mathrm{PP}-\mathrm{Fe} e^{I I I}\right]^{+}$and in green for $\left[\mathrm{HPP}-\mathrm{Fe}-\mathrm{H}_{2} \mathrm{O}\right]^{+} /[\mathrm{HPP}-\mathrm{Fe}]^{+}$. In Figure 4, the variation of $\operatorname{Ln}\left(I_{\left[\mathrm{HPP}-\mathrm{Fe}-\mathrm{H}_{2} \mathrm{O}\right]^{+}} / I_{[\mathrm{HPP}-\mathrm{Fe}]^{+}}\right)$with $1 / \mathrm{T}$ has a smaller slope compared to the equivalent for ferric heme. This is due to the decrease of the water vapor pressure with temperature below $175 \mathrm{~K}$. Nevertheless the slopes of the non protonated equilibrium (blue) and that of the protonated (green) differ by a ratio of 4 . Since the fitted concentration of the protonated water complex varies in a constant manner, it ensures that the presence of a protonated complex is necessary to the fit. This allows placing an upper limit to the binding of $\left[\mathrm{H} \mathrm{PP}-\mathrm{Fe}-\mathrm{H}_{2} \mathrm{O}\right]^{+}$as $\approx 12.2 / 4=3.1 \mathrm{kcal}^{-\mathrm{mol}^{-1}}$, a fourfold decrease in binding, however biased by the variation of the water vapor pressure. 


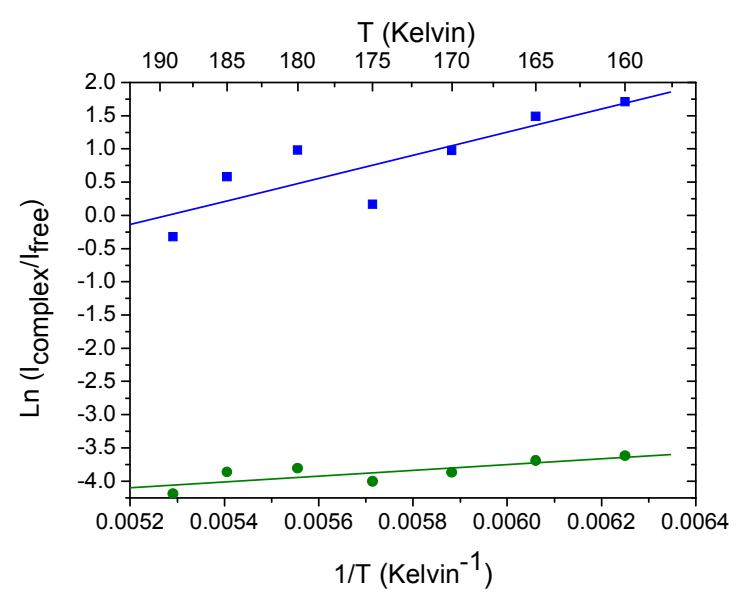

Figure 4: Simultaneous plots of $\left[\mathrm{PP}-\mathrm{Fe} e^{I I I}-\mathrm{H}_{2} \mathrm{O}\right]^{+} /\left[\mathrm{PP}_{-} \mathrm{Fe} e^{I I I}\right]^{+}$(blue) and $\left[\mathrm{HPP}-\mathrm{Fe}-\mathrm{H}_{2} \mathrm{O}\right]^{+} /[\mathrm{H} \mathrm{PP}-\mathrm{Fe}]^{+}$(green).

\section{4-1-3 Excitation spectrum of the water ferric Heme complex}

The excitation spectrum of the $\left[\mathrm{PP}-\mathrm{Fe}^{\mathrm{III}}-\mathrm{H}_{2} \mathrm{O}\right]^{+}$can be obtained after tunable laser excitation by monitoring the loss of $\mathrm{H}_{2} \mathrm{O}$. Through the 420-800 nm wavelength domain, a broad band is found as for other ferric porphyrins at $\sim 520 \mathrm{~nm}$, corresponding to the vibronic Qv bands and a weaker broad band appears around $617 \mathrm{~nm}$ (see Figure 5a). This latter band, although weak, is located in the same region as the charge transfer band found in the action spectrum of $\left[\mathrm{PP}-\mathrm{Fe}^{\mathrm{III}-}-\mathrm{N}_{2}\right]^{+}$ represented in Figure 5 at $610 \mathrm{~nm}$ (Figure 5b). No intense extension of the [PP-Fe $\left.e^{\mathrm{III}}-\mathrm{H}_{2} \mathrm{O}\right]^{+}$ spectrum was detected beyond $650 \mathrm{~nm}$. This water complex spectrum is compared in Figure $5 \mathrm{~b}$ with that of ferric heme complexed with dinitrogen, a very weak ligand acting as a molecular $\operatorname{tag}^{29}$ and yielding a similar spectrum to that of free ferric heme. It appears that both spectra have a similar shape in this wavelength domain, but the lower spectrum is narrower; this could be related with the much lower temperature at which it was recorded, $22 \mathrm{~K}^{4}$. 


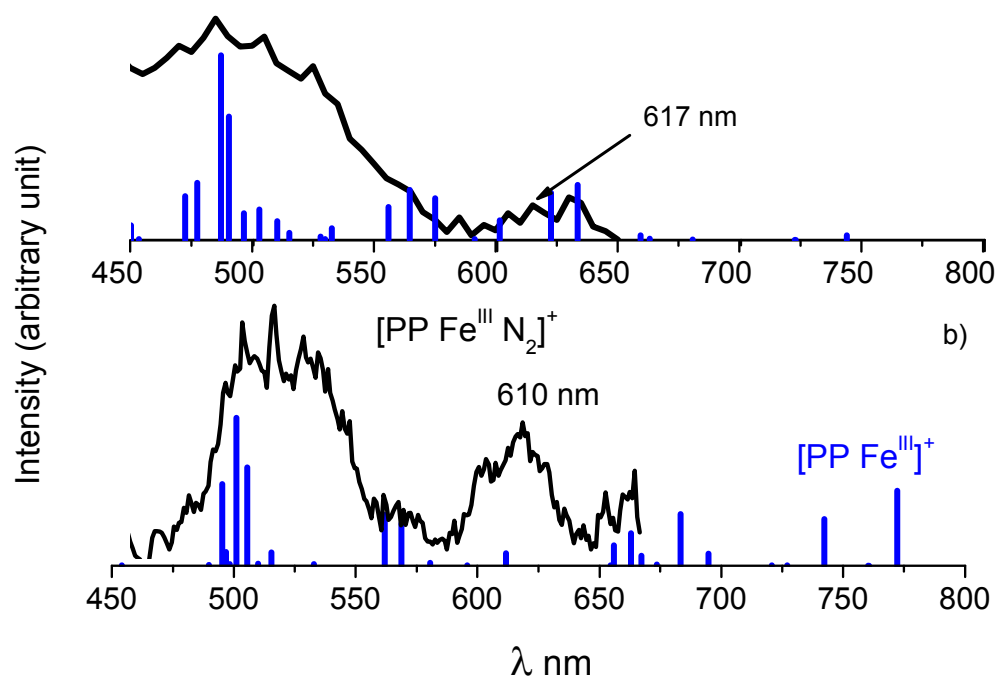

Figure 5a): Action spectrum of the $\left[\mathrm{PP}-\mathrm{Fe}^{\mathrm{III}}-\mathrm{H}_{2} \mathrm{O}\right]^{+}$complex observed by $\left[\mathrm{PP}-\mathrm{Fe} e^{I I I}\right]^{+}$detection obtained at $T_{\text {Trap }}=155 \mathrm{~K}$ (black). Calculated absorption spectrum, blue (see text). b) Action spectrum of the weakly bound $\left[\mathrm{PP}-\mathrm{F} e^{\mathrm{III}}-\mathrm{N}_{2}\right]^{+}$complex at $T_{\text {Trap }}=22 \mathrm{~K}$ (black) and the calculated spectrum of $\left[\mathrm{PP}-\mathrm{Fe} e^{I I I}\right]^{+}$(blue). The comparison is made assuming a negligible perturbation by $\mathrm{N}_{2}$ of $\left[\mathrm{PP}-\mathrm{Fe}^{I I I}\right]^{+}$.

\section{4-2-Theoretical Results:}

\section{4-2-1: Optimized geometries and Binding Energies:}

In addition to global heme structures, several conformers may arise from the different orientations of carboxyl groups and other side-chains with respect to the core porphyrin ring. Thus, we have investigated different orientations of side-chain branches and carbocyclic moieties. In agreement with previous studies of Dillinger et al. ${ }^{7}$, it has been predicted that the cis conformer presented in

Figure 6 is the most stable structure, stabilized by two strong hydrogen bonds between the carboxyl groups. 
a) $\left[\mathrm{PP}-\mathrm{Fe}^{\mathrm{III}}\right]^{+}$

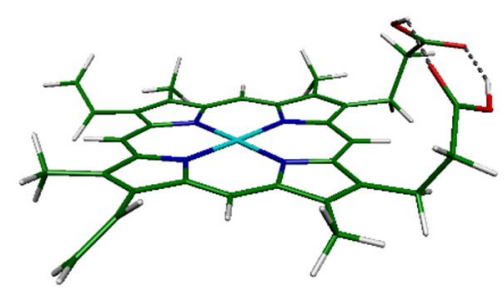

b) $\left[\mathrm{PPFe}^{\mathrm{III}}-\mathrm{H}_{2} \mathrm{O}\right]^{+}$

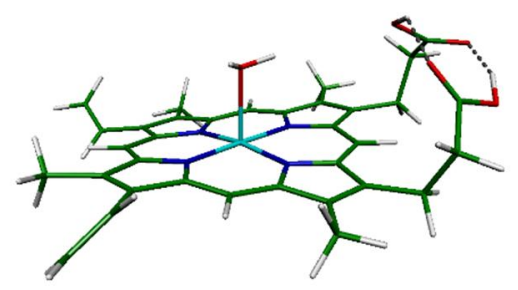

c) $\left[\mathrm{PPH}-\mathrm{Fe}-\mathrm{H}_{2} \mathrm{O}\right]^{+}$

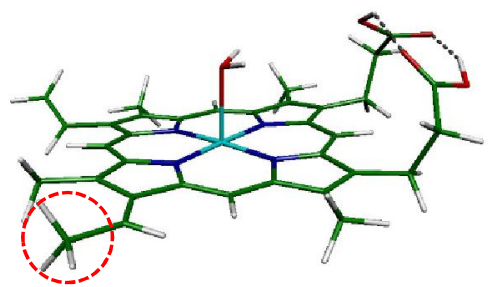

Figure 6: Optimized structures for the most stable spin state of ferric heme complexes. a) Free ferric heme, $b \mathrm{H}_{2} \mathrm{O}$ ligated to ferric heme and c) ligated to protonated ferric heme. The red circle shows the most probable location of the excess proton in c). All structures have been determined at the OPBE level of theory. All three complexes are in their intermediate spin state either $3 / 2$ for ferric heme or 1 for protonated heme.

In addition to the geometry of the free $\left[\mathrm{PP}-\mathrm{Fe}^{\mathrm{III}}\right]^{+}$systems, we have investigated the $\mathrm{H}_{2} \mathrm{O}$ heme complexes [PP- $\left.\mathrm{Fe}^{\mathrm{III}} \mathrm{H}_{2} \mathrm{O}\right]^{+}$in their optimized geometries, considering the three possible spin states; $\mathrm{S}=1 / 2$ (doublet), $\mathrm{S}=3 / 2$ (quartet) and $\mathrm{S}=5 / 2$ (sextet). The relative spin state energies at the OPBE level are summarized in Table S1, ESI file. The quartet spin state of $\left[\mathrm{PP}-\mathrm{Fe}^{\mathrm{III}}-\mathrm{H}_{2} \mathrm{O}\right]^{+}$was found to

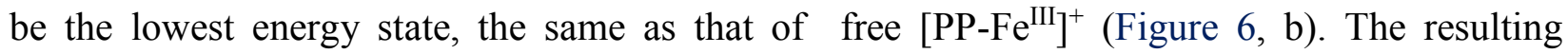
stabilization energy after water binding energy was calculated to be $-11.7 \mathrm{kcal}^{\mathrm{mol}}{ }^{-1}$ at the OPBE level Table 1. The doublet and sextet states are also higher in energy by 25.44 and $7.55 \mathrm{kcal}^{\mathrm{mol}}{ }^{-1}$ respectively, compared with the most stable $3 / 2$ spin state.

To account for the effect of the $6^{\text {th }}$ coordinated ligation on the binding energy, the geometry of the doubly complexed $\left[\mathrm{PP}-\mathrm{Fe}^{\mathrm{III}}-\left(\mathrm{H}_{2} \mathrm{O}\right)_{2}\right]^{+}$and $\left[\mathrm{MI}-\mathrm{PP}-\mathrm{Fe}^{\mathrm{III}}-\mathrm{H}_{2} \mathrm{O}\right]^{+}$were also optimized in the $3 / 2$ and $5 / 2$ spin states respectively, by adding a second water molecule or MI to the $6^{\text {th }}$ coordination site. The binding energies and the most important structural parameters are presented in Table 1 and Table 2, respectively. It is found that the strongest $\mathrm{Fe}-\mathrm{O}$ bond is related to the ferric $\left[\mathrm{PP}-\mathrm{Fe} \mathrm{F}^{\mathrm{III}}-\mathrm{H}_{2} \mathrm{O}\right]^{+}$ singly coordinated water complex, while the second $\mathrm{Fe}-\mathrm{O}$ bond is calculated as equivalent for [PP$\left.\mathrm{Fe}^{\mathrm{III}}-\left(\mathrm{H}_{2} \mathrm{O}\right)_{2}\right]^{+},-7.14 \mathrm{kcal}^{\mathrm{mol}}{ }^{-1}$, and $\left[\mathrm{MI} \mathrm{PP}-\mathrm{Fe}^{\mathrm{III}}-\mathrm{H}_{2} \mathrm{O}\right]^{+},-7.44 \mathrm{kcal}^{-\mathrm{mol}^{-1}}$. 


\begin{tabular}{|c|c|c|c|c|c|c|c|}
\hline \multirow{2}{*}{ Complex } & \multirow{2}{*}{$\begin{array}{l}\text { Spin } \\
\text { state }\end{array}$} & \multicolumn{5}{|c|}{ Theory } & \multirow{2}{*}{$\frac{\text { Experiment }}{\Delta \mathrm{E}}$} \\
\hline & & $\Delta \varepsilon$ & $\mathrm{ZPE}$ & BSSE & dispersion & $\Delta \mathrm{E}_{\mathrm{c}}^{\mathrm{a}}$ & \\
\hline 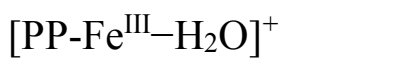 & $3 / 2$ & -5.73 & 2.63 & 0.63 & -9.21 & -11.68 & $-12.2 \pm 0.6$ \\
\hline$\left[\mathrm{H} \mathrm{PP}-\mathrm{Fe}-\mathrm{H}_{2} \mathrm{O}\right]^{+}$ & 1 & -3.39 & 2.33 & 0.61 & -9.17 & -9.62 & $\begin{array}{c}\text { Weakly } \\
\text { formed }>-3.1\end{array}$ \\
\hline$\left[\mathrm{PP}-\mathrm{Fe}^{\mathrm{II}}-\mathrm{H}_{2} \mathrm{O}\right]$ & 1 & 0.65 & 1.96 & 0.60 & -9.27 & -6.06 & - \\
\hline$\left[\mathrm{PP}-\mathrm{Fe}^{\mathrm{III}}-\left(\mathrm{H}_{2} \mathrm{O}\right)_{2}\right]^{+\mathrm{c}}$ & $3 / 2$ & -1.22 & 2.16 & 0.59 & -8.67 & -7.14 & $-9 \pm 0.9$ \\
\hline$\left[\mathrm{H} \mathrm{PP}-\mathrm{Fe}-\left(\mathrm{H}_{2} \mathrm{O}\right)_{2}\right]^{+\mathrm{c}}$ & 1 & -0.25 & 1.98 & 0.58 & -8.32 & -6.01 & $\underset{b}{\text { Not observed }}$ \\
\hline$\left[\mathrm{PP}-\mathrm{Fe}^{\mathrm{II}}-\left(\mathrm{H}_{2} \mathrm{O}\right)_{2}\right]^{\mathrm{c}}$ & 1 & 1.48 & 1.67 & 0.53 & -8.36 & -4.68 & - \\
\hline$\left[\mathrm{MI}-\mathrm{PP}-\mathrm{Fe}^{\mathrm{III}}-\mathrm{H}_{2} \mathrm{O}\right]^{+\mathrm{c}}$ & $5 / 2$ & 1.99 & 2.23 & 0.61 & -12.27 & -7.44 & $>-7^{b}$ \\
\hline
\end{tabular}

Table 1: Calculated and experimental electronic binding energies $(\Delta \varepsilon, \Delta E)$ (in $\left.\mathrm{kcal} . \mathrm{mol}^{-1}\right)$ for the reaction of $\mathrm{X}+\mathrm{H}_{2} \mathrm{O} \rightarrow\left[\mathrm{X}-\mathrm{H}_{2} \mathrm{O}\right]\left(\mathrm{X}=\left[\mathrm{PP}-\mathrm{Fe} e^{I I I}\right]^{+},\left[\mathrm{H}_{2} \mathrm{OPP}-\mathrm{Fe}^{I I I}\right]^{+},\left[\mathrm{MI} \mathrm{PP}-\mathrm{Fe}^{I I I}\right]^{+}\left[\mathrm{H} \mathrm{PP}-\mathrm{Fe} e^{I I I}\right]^{+}\right)$, in various ligation condition $5^{\text {th }}$ ligation and $6^{\text {th }}$ ligation (see text). The theoretical value has been calculated using single point OPTX-PBE/cc-pVTZ (aug-cc-pVTZ for $F e, O$ and $N$ ) calculations on previously optimized structures at the OPTX-PBE/DZVP-GGA level.

a) $\triangle E_{c}$ stands for the corrected binding energy with ZPE, dispersion and BSSE (see text).

b) These complexes are weakly observed in the ion trap, in our experimental conditions. The binding energy

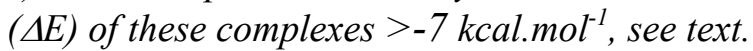

c) six coordinated heme with two ligands $\mathrm{H}_{2} \mathrm{O}$ or MI on each porphyrin face.

Moreover, we have determined the optimized structure of protonated ferric heme $[\mathrm{H} \mathrm{PP}-\mathrm{Fe}]^{+}$, and ferrous heme $\left[\mathrm{PP}-\mathrm{Fe}^{\mathrm{II}}\right]$. In the case of $[\mathrm{H} \mathrm{PP}-\mathrm{Fe}]^{+}$, only the most stable protonated isomer previously assigned by Chiavarino et al. ${ }^{14}$ has been considered (i.e. where the extra proton locates at the $\beta$ carbon of one vinyl group at $\mathrm{C} 7$, see Figure 6.c). It is also shown that for protonated ferric heme $[\mathrm{H} \mathrm{PP}-\mathrm{Fe}]^{+}$and ferrous heme, the triplet state is the lowest energy isomer. We have optimized the triplet state of $[\mathrm{H} \mathrm{PP}-\mathrm{Fe}]^{+}$(Figure 6-c) and [PP-Fe $\left.{ }^{\mathrm{II}}\right]$ at the same theoretical level as for its [PP$\left.\mathrm{Fe}^{\mathrm{III}}\right]^{+}$homologue and determined the binding energy with water. As shown in Table 1, protonation of heme decreases the binding affinity of the first water molecule by $\sim 2 \mathrm{kcal}^{\mathrm{mol}}{ }^{-1}$ while the ferrous heme water complex is $\sim 5.6 \mathrm{kcal}_{\mathrm{mol}}^{-1}$ less stable than the ferric heme complex. Smaller reductions by protonation or reduction to ferrous heme are calculated for doubly water-coordinated complexes. 
We have also collected selected parameters of the optimized geometries of different systems (ligated and unligated ferric heme and protonated homologues) in Table 2. More details on the optimized structures and xyz coordinates can be found in ESI file (see Figure 6 and Table S2, S6 in ESI file). From the results, it is seen that the porphyrin ring in $\left[\mathrm{PP}-\mathrm{Fe}^{\mathrm{III}}\right]^{+}$preserves its planarity following optimization, while the ring is slightly distorted or saddled in protonated and singly $\mathrm{H}_{2} \mathrm{O}$ ligated systems. Also, in [MI-PP-Fe $\left.\mathrm{F}^{\mathrm{III}}\right]^{+}$, it appears that the central iron moves out of porphyrin ring (being attracted by MI, resulting in reverse doming). Doming is predicted to be more prominent in [MI-PP-Fe $\left.{ }^{\mathrm{III}}\right]^{+}$(by $0.411 \AA$ ) but decreases by $6^{\text {th }}$ coordination to $\mathrm{H}_{2} \mathrm{O}$. Also, in Table 2 , the larger values predicted for doming are accompanied by longer Fe-Np bond-lengths. The related $\mathrm{Fe}-\mathrm{O}$ bond lengths decreases from low- to high-spin state, in the quartet state, the $\mathrm{H}_{2} \mathrm{O}$ distance to the $\mathrm{Fe}$ is $2.28 \AA$ while the Fe-O distances is $2.43 \AA$ for the sextet state.

The structure of the $\left[\mathrm{PP} \mathrm{Fe}^{\mathrm{III}}-\mathrm{H}_{2} \mathrm{O}\right]^{+}$complex is of helicopter type, with the $\mathrm{OH}$ bonds not far from parallel to the heme plane, with a $\angle \mathrm{FeOH}$ angle of $109^{\circ}$ as shown in Table 2 and Figure 6 . The $\mathrm{O}$ atom in $\mathrm{H}_{2} \mathrm{O}$ is distant by $2.281 \AA$ from the $\mathrm{Fe}$ atom. This value is larger than the results of the $\mathrm{X}$-Ray data, $2.039 \AA$, for $\left[\mathrm{Fe} \mathrm{e}^{\mathrm{III}} \mathrm{TPP}-\mathrm{H}_{2} \mathrm{O}\right]^{+}$(ferric tetraphenyl porphyrin water complex). The experimental structure of $\left[\mathrm{Fe}^{\mathrm{III}} \mathrm{TPP}-\mathrm{H}_{2} \mathrm{O}\right]^{+}$exhibits the same cage parameter, the $\mathrm{Fe}$ atom$\mathrm{N}$ (pyrrole) atom distance, $1.979 \AA$ as the calculated system [PP-Fe $\left.{ }^{\mathrm{III}}-\mathrm{H}_{2} \mathrm{O}\right]^{+}, 1.974 \AA$, confirming the present theoretical structure. To account for the difference in the calculated Fe-O distance and the model crystallographic system, in Ref. ${ }^{8}\left[\mathrm{PP} \mathrm{Fe}^{\mathrm{III}}-\left(\mathrm{H}_{2} \mathrm{O}\right)_{2}\right]^{+}$with a $\left(\mathrm{CB}_{11} \mathrm{H}_{6} \mathrm{Cl}_{6}\right)^{-}$counter-ion, we calculated that latter structure, which is somehow different from ours, since the ligated $\mathrm{H}_{2} \mathrm{O}$ molecule is polarized in the crystal by a second water molecule and a large counter ion. Indeed, in these conditions with a second adjacent water molecule and the counter-ion $\left(\mathrm{CB}_{11} \mathrm{H}_{6} \mathrm{Cl}_{6}\right)^{-}$, the calculated Fe-O bond length is reduced by $0.15 \AA$ to $2.135 \AA$ closer to the $2.039 \AA$ diffraction value, as shown in Figure S2, ESI. Therefore the Fe-O bond distance is a sensitive detection of the polarization of this bond by various influences. 


\begin{tabular}{|c|c|c|c|c|c|c|}
\hline Complex & $\mathrm{S}$ & $\mathrm{Fe}-\mathrm{O}$ & Doming $^{\text {a }}$ & $\mathrm{Fe}-\mathrm{N}_{\mathrm{P}}^{\mathrm{b}}$ & $\mathrm{Fe}-\mathrm{N}_{\mathrm{MI}}$ & $\angle \mathrm{FeOH}$ \\
\hline$\left[\mathrm{PP}-\mathrm{Fe}^{\mathrm{III}}\right]^{+}$ & $3 / 2$ & - & -0.006 & 1.963 & - & - \\
\hline Exp. $^{30}$ & & - & 0.000 & 1.950 & - & - \\
\hline$\left[\mathrm{H} \text { PP-Fe }{ }^{\mathrm{II}}\right]^{+}$ & 1 & - & -0.011 & 1.973 & - & - \\
\hline$\left[\mathrm{PP}-\mathrm{Fe}^{\mathrm{II}}\right]$ & 1 & - & -0.007 & 1.980 & - & - \\
\hline$\left[\mathrm{PP}-\mathrm{Fe}^{\mathrm{III}}-\mathrm{H}_{2} \mathrm{O}\right]^{+}$ & $3 / 2$ & 2.281 & +0.083 & 1.974 & - & 109.0 \\
\hline Exp. $^{8}$ & & 2.039 & - & 1.979 & - & - \\
\hline$\left[\mathrm{H} \mathrm{PP}-\mathrm{Fe}-\mathrm{H}_{2} \mathrm{O}\right]^{+}$ & 1 & 2.340 & +0.045 & 1.980 & - & 107.0 \\
\hline$\left[\mathrm{PP}-\mathrm{Fe}^{\mathrm{II}}-\mathrm{H}_{2} \mathrm{O}\right]$ & 1 & 2.478 & +0.030 & 1.985 & - & 99.85 \\
\hline$\left[\mathrm{PP}-\mathrm{Fe}^{\mathrm{III}}-\left(\mathrm{H}_{2} \mathrm{O}\right)_{2}\right]^{+\mathrm{c})}$ & $3 / 2$ & 2.368 & - & 1.990 & - & 107.4 \\
\hline$\left[\mathrm{H} \mathrm{PP}-\mathrm{Fe}-\left(\mathrm{H}_{2} \mathrm{O}\right)_{2}\right]^{+\mathrm{c})}$ & 1 & 2.410 & -0.015 & 1.994 & - & 107.9 \\
\hline$\left[\mathrm{PP}-\mathrm{Fe}^{\mathrm{II}}-\left(\mathrm{H}_{2} \mathrm{O}\right)_{2}\right]^{\mathrm{c})}$ & 1 & 2.616 & +0.002 & 1.993 & - & 92.1 \\
\hline$\left[\mathrm{MI}-\mathrm{PP}-\mathrm{Fe}^{\mathrm{III}}-\left(\mathrm{H}_{2} \mathrm{O}\right)\right]^{+}$ & $5 / 2$ & 2.438 & $-0.120^{\mathrm{d})}$ & 2.059 & 2.169 & 106.3 \\
\hline$\left[\mathrm{MI}-\mathrm{PP}-\mathrm{Fe}^{\mathrm{IIII}}\right]^{+}$ & $5 / 2$ & - & $-0.411^{\mathrm{d}}$ & 2.073 & 2.115 & - \\
\hline
\end{tabular}

Table 2: Selected optimized geometry parameters (in A and deg.) at the OPTX-PBE/DZVP-GGA level, of the heme complexes detailed in Table 1: a) doming distance of the Fe atom from the porphyrin plane, defined as the distance from the line joining two pyrrole $N$ atoms; b) Np, pyrrole nitrogen atoms. c) six coordinated heme with $\mathrm{H}_{2} \mathrm{O}$ on each porphyrin face. d) inverse doming towards MI.

\section{4-2-2 Fe-O bond analysis}

In order to further explore the nature of the $\mathrm{Fe}^{\mathrm{III}}-\mathrm{O}$ interaction, we performed a detailed topological analysis based on the Bader's theory of "Quantum Theory of Atoms in Molecules" (QTAIM) and 
also on the "Electron Localization Function (ELF)". A brief description of ELF and AIM methods can be found in section 3 .

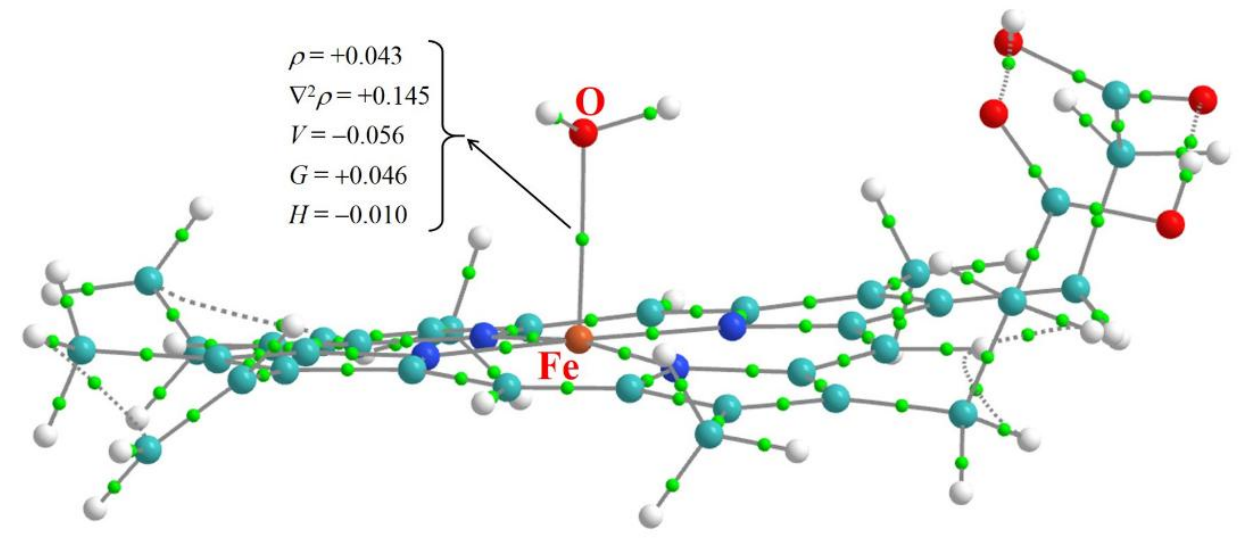

Figure 7- The QTAIM (Quantum Theory of Atoms in Molecules) molecular graph of [PP-Fe $\left.{ }^{\mathrm{III}}-\mathrm{H}_{2} \mathrm{O}\right]^{+}$ species in ground spin state. The larger spheres represent attractors attributed to atomic nuclei and the small green spheres show the bond critical points. Solid lines represent the bond paths. The critical point $\mathrm{BCP}$ for the $\mathrm{Fe} \mathrm{O}$ bond is distant by $1.11 \AA$ from the $\mathrm{Fe}$ atom. All values (see text) in the figure are in atomic units.

The relevant topological graph for ground spin state $(S=3 / 2)$ is depicted in Figure 7, where the bond critical points are displayed as green dots. For the $\mathrm{Fe}-\mathrm{O}$ bond, the values of the important parameters at $\mathrm{BCP}$ of $\nabla^{2} \rho_{\mathrm{BCP}}=+0.145$ at $\mathrm{BCP}$ and the total electron energy density, $\mathrm{H}(\mathrm{BCP})=$ 0.010 a.u.. With $\mathrm{H}(\mathrm{BCP})<0$ the local potential electron energy dominates and the localization of the electron density $\rho(.04)$ at the BCP has a stabilizing impact on the bond.

\section{4-2-3 Hirshfeld spin populations}

The spin state of ferric heme characterizes the electron distributions about the Fe atom, the ligand and the pyrrole $\mathrm{N}$-atoms. The calculated most stable spin states are the same for the free and $\mathrm{H}_{2} \mathrm{O}$ complexed ferric heme, the intermediate state $(S=3 / 2)$, with 3 unpaired electrons. This agrees with measurements on the homologous complex $\left[\mathrm{FeTPP}-\mathrm{H}_{2} \mathrm{O}\right]^{+}(\mathrm{TPP}=$ tetraphenyl porphyrin), where a magnetic moment $\left(\mu_{\mathrm{eff}}=4.1 \mu_{\mathrm{B}}\right)$ indicated a quartet state ${ }^{8}$. Together ${ }^{1} \mathrm{H}-\mathrm{NMR}$ shifts of the pyrrole $\mathrm{H}$-atoms characterize Fe porphyrin quartet states ${ }^{30}$. The action spectrum in Figure 5 reflects this 
$3 / 2$ spin state by the presence of charge transfer bands in the red region of the spectrum, that are not present in low spin Fe porphyrin systems. Table 3 also collects the Hirschfeld spin densities for the most important atoms of the heme complexes under study, allowing a mapping of the unpaired electron distribution.

For comparison, we also calculated the spin densities for the corresponding ferrous hemes and included them in Table 3. It is seen that in ferric complexes, the 3 unpaired electrons are dominantly located on the Fe atom with an integrated value of $\sim 2.44$, associated with a significant distribution of the spin density on four $\mathrm{Np}$ atoms of the pyrrolic rings and a negligible value on the $\mathrm{H}_{2} \mathrm{O}$ moiety. A total value close to 3 for $\mathrm{Fe}$ and the neighboring $\mathrm{Np}$ atoms, points to the $\left[\mathrm{PP}-\mathrm{Fe}{ }^{\mathrm{III}}(\mathrm{S}=3 / 2)-\mathrm{OH}_{2}\right.$ $(\mathrm{S}=0)]^{+}$electronic structure in which both interacting species preserve their spin states upon complexation. Therefore, ligation of $\mathrm{H}_{2} \mathrm{O}$ to the ferric heme system, is accompanied only by slight alterations of the electronic configuration of the $\mathrm{Fe}^{\mathrm{III}}$ center, hence water can be assumed as a "weak" ligand interacting with ferric heme. This also indicates the fact that ferric heme preserves its spin state following binding to $\mathrm{H}_{2} \mathrm{O}$.

Protonated heme complexes, however exhibit a different behavior. The iterative Hirshfeld spin density distributions collected in Table 3 show that a majority of the $\alpha$ spin density in the protonated heme complexes is distributed about the central $\mathrm{Fe}$ atom, while a significant excess of $\beta$ spin density is gained by the vinyl $\alpha$-carbon. This points to an ethyl radical character for the vinyl group, with a $\left[\mathrm{H}^{\circ} \mathrm{PP}-\mathrm{Fe}^{\mathrm{III}}-\mathrm{H}_{2} \mathrm{O}\right]^{+}$electronic structure. Chiavarino et al. ${ }^{14}$ have ascribed this situation to a partial transfer of an electron from a $\mathrm{Fe}^{\mathrm{II}}$ central atom to the free protonated porphyrin ring. Furthermore, comparing the $\alpha$ spin densities on the Fe atom in protonated heme complexes with that of the ferric and natural ferrous ones (see Table 3), we found an intermediate situation between $\left[\mathrm{H}^{+} \mathrm{PP}-\mathrm{Fe}^{\mathrm{II}}-\mathrm{H}_{2} \mathrm{O}\right]$ and $\left[\mathrm{H}^{\bullet} \mathrm{PP}-\mathrm{Fe}^{\mathrm{III}}-\mathrm{H}_{2} \mathrm{O}\right]^{+}$electronic structures. This result is in complete agreement with the findings of Chiavarino et al. ${ }^{14}$ on free protonated heme. It is worth mentioning that double ligation by water does not change this behavior. In addition, in the case of ferrous heme the same conclusions can be drawn, where ligation with $\mathrm{H}_{2} \mathrm{O}$ does not alter the spin and the number of unpaired electrons on the Fe atom as characterized by its $\alpha$ spin, see Table 3 . 


\begin{tabular}{|c|c|c|c|c|c|c|c|}
\hline Complex & $\begin{array}{l}\text { Fe spin } \\
\text { density }\end{array}$ & $\begin{array}{l}\text { Integrated } \\
\text { spin density } \\
\text { of the } 4 \\
\text { Np's }\end{array}$ & $\begin{array}{c}\mathrm{O} \\
\left(\mathrm{H}_{2} \mathrm{O}\right) \\
\text { spin } \\
\text { density }\end{array}$ & $\begin{array}{c}\mathrm{H}_{2} \mathrm{O} \\
\text { Integrated } \\
\text { spin } \\
\text { density }\end{array}$ & $\begin{array}{l}\text { Vinyl } \alpha- \\
\text { carbon } \\
\text { spin } \\
\text { density }\end{array}$ & $\begin{array}{c}\text { Remaining } \\
\text { Integrated } \\
\text { spin } \\
\text { density }\end{array}$ & $\begin{array}{l}\text { Integrated } \\
\text { spin } \\
\text { density of } \\
\text { the } \\
\text { complex }\end{array}$ \\
\hline$\left[\mathrm{PP}-\mathrm{Fe}^{\mathrm{III}}\right]^{+}$ & 2.44 & 0.18 & - & - & 0.0 & 0.38 & 3.0 \\
\hline$[\mathrm{H} \text { PP-Fe }]^{+}$ & 2.19 & 0.05 & - & - & -0.11 & -0.13 & 2.0 \\
\hline$\left[\mathrm{PP}-\mathrm{Fe}^{\mathrm{II}}\right]$ & 2.02 & 0.04 & - & - & 0.00 & -0.06 & 2.0 \\
\hline$\left[\mathrm{PP}-\mathrm{Fe}^{\mathrm{IIII}}-\mathrm{H}_{2} \mathrm{O}\right]^{+}$ & 2.45 & 0.14 & 0.09 & 0.09 & 0.0 & 0.32 & 3.0 \\
\hline$\left[\mathrm{H} \mathrm{PP}-\mathrm{Fe}-\mathrm{H}_{2} \mathrm{O}\right]^{+}$ & 2.22 & 0.03 & 0.07 & 0.08 & -0.15 & -0.18 & 2.0 \\
\hline$\left[\mathrm{PP}-\mathrm{Fe}^{\mathrm{II}}-\mathrm{H}_{2} \mathrm{O}\right]$ & 2.04 & 0.02 & 0.05 & 0.05 & 0.00 & -0.11 & 2.0 \\
\hline$\left[\mathrm{PP}-\mathrm{Fe}^{\mathrm{IIII}}-\left(\mathrm{H}_{2} \mathrm{O}\right)_{2}\right]^{+}$ & 2.49 & 0.08 & 0.07 & 0.08 & 0.0 & 0.35 & 3.0 \\
\hline$\left[\mathrm{H} \mathrm{PP}-\mathrm{Fe}-\left(\mathrm{H}_{2} \mathrm{O}\right)_{2}\right]^{+}$ & 2.29 & -0.01 & 0.06 & 0.06 & -0.17 & -0.17 & 2.0 \\
\hline$\left[\mathrm{PP}-\mathrm{Fe}^{\mathrm{II}}-\left(\mathrm{H}_{2} \mathrm{O}\right)_{2}\right]$ & 2.06 & -0.0 & 0.05 & 0.05 & 0.00 & -0.11 & 2.0 \\
\hline
\end{tabular}

Table 3: Iterative Hirshfeld spin populations of selected atoms obtained from the OPTX-PBE electron densities.

\section{4-2-4 Simulation of the absorption spectra}

The spectra of water complexed ferric heme $\left[\mathrm{PP}-\mathrm{Fe}^{\mathrm{III}}-\mathrm{H}_{2} \mathrm{O}\right]^{+}$and of the free heme $\left[\mathrm{PP}-\mathrm{Fe}^{\mathrm{III}}\right]^{+}$have been simulated with their optimized geometries (OPBE). The calculated spectrum of [PP$\left.\mathrm{Fe}^{\mathrm{III}}-\mathrm{H}_{2} \mathrm{O}\right]^{+}$is represented in the $450-800 \mathrm{~nm}$ domain in Figure 5a with blue sticks. The electronic transitions and relevant oscillator strengths have been determined at the TD-DFT/B3LYP level. The main absorption features of the experimental spectrum have been reproduced as shown in Figure 5a. The complete calculated spectrum is shown in Figure S3A of ESI and displays the most 
intense bands close to $370 \mathrm{~nm}$ in the known intense experimental Soret region. The calculated spectrum of the free heme $\left[\mathrm{PP}-\mathrm{Fe}^{\mathrm{III}}\right]^{+}$is also represented in Figure $5 \mathrm{~b}$, together with the experimental spectrum of $\left[\mathrm{PP}-\mathrm{Fe}^{\mathrm{III}}-\mathrm{N}_{2}\right]^{+}$, which we deem as closest to free $\left[\mathrm{PP}-\mathrm{Fe}^{\mathrm{III}}\right]^{+}$, owing to the very weak interaction of $\mathrm{N}_{2}$ with $\mathrm{Fe}^{\mathrm{III} 4,27}$.

For [PP-Fe $\left.{ }^{\mathrm{III}}-\mathrm{H}_{2} \mathrm{O}\right]^{+}$, in the $450-700 \mathrm{~nm}$ region, the wave function analysis shows two regions: one with dominant porphyrin transitions between $500600 \mathrm{~nm}$ and another with important porphyrin to metal transitions detailed in Table S3 in ESI file. For free heme [PP-Fe $\left.{ }^{\mathrm{III}}\right]^{+}$, the $500600 \mathrm{~nm}$ region has a similar porphyrin character, while a strongly red shifted porphyrin to metal transition is calculated at $683 \mathrm{~nm}$.

The calculated spectrum of free ferric heme and that of its $\mathrm{N}_{2}$ complex extend to $700 \mathrm{~nm}$ and the band positions beyond $600 \mathrm{~nm}$ are red shifted from the experimental spectrum. While the experimental spectrum for [PP-Fe $\left.\mathrm{IIII}_{-} \mathrm{N}_{2}\right]^{+}$stops at $670 \mathrm{~nm}$, there is no experimental evidence of such intense bands at $800 \mathrm{~nm}$ as those shown in Figure 5b, in any of the ferric porphyrins. Indeed, bands exist in that domain but with a considerably lesser oscillator strength ${ }^{31}$, similar to that calculated for the $\left[\mathrm{PP}-\mathrm{Fe}^{\mathrm{III}}-\mathrm{H}_{2} \mathrm{O}\right]^{+}$spectrum at $850 \mathrm{~nm}$ (Figure S3 ESI). It may seem that the wavefunction representation overemphasizes the metal centered oscillator strengths for free ferric heme.

\section{5-Discussion}

The $\left[\mathrm{PP}-\mathrm{Fe}^{\mathrm{III}}-\mathrm{H}_{2} \mathrm{O}\right]^{+}$complex is axially ligated as shown in Figure 6 with an helicopter like configuration for the water ligand, in agreement with crystallographic measurements on $\mathrm{Fe}^{\mathrm{III}}$ porphyrin water complexes ${ }^{8}$. This geometry is similar to that found in met-myoglobin by crystallography ${ }^{1}$ and represents the basis for the construction of water heme ligands, see Table 2 .

\section{5-1 Structure of the Heme- $\mathrm{H}_{2} \mathrm{O}$ complexes}

Basic electron donating ligands are bound to ferric heme by $\sigma$ bonds with the $\mathrm{Fe}\left(3 \mathrm{~d}_{\mathrm{z} 2}\right)$ orbital. In the case of water, the oxygen $\pi\left(b_{2}\right)$ lone pair coordinates with the $\mathrm{Fe}^{\mathrm{III}}\left(3 \mathrm{~d}_{\mathrm{z} 2}\right)$ axial orbital. No 
backbonding from a $\pi$ type $\mathrm{Fe}\left(3 \mathrm{~d}_{\mathrm{xz}, \mathrm{yz}}\right)$ orbital is occurring, in contrast with other small ligands, typically CO. Therefore the coordination of " $\sigma$ donors" to iron porphyrins is correlated to the Lewis basicity of the donor, the ability to share a lone pair with an acceptor molecule, ref $^{32} \mathrm{p} 142$. In this view, the ligation of nitrogen bases of various strengths has been studied in the condensed phase by equilibrium measurements ${ }^{33}$. However, the difficulty of these experiments is the full control of a single ligation, which is superseded by the axial bi-ligation in a narrow range of concentrations of the ligand and also by the formation of $\mu$ hydroxo complexes [(PP)-Fe-OH-Fe-(PP)]+ at higher concentrations of metalloporphyrins ${ }^{8}$.

In the theoretical and previous crystallographic results, $\left[\mathrm{PP}-\mathrm{Fe}-\mathrm{H}_{2} \mathrm{O}\right]^{+}$has the water hydrogen atoms placed in a plane quasi parallel to heme and the $\pi\left(b_{2}\right)$ lone pair of the $\mathrm{O}$ atom is between the $\mathrm{O}$ and $\mathrm{Fe}$ atoms. This generates in the ELF distributions a basin between these atoms, as shows in Figure S4 of ESI. This basin contains however almost no contribution of the Fe atom, hence no information on the sharing of $\mathrm{Fe}$ and $\mathrm{O}$ electrons of the Fe-O bond (covalency) can be drawn at this level. In turn, the QTAIM analysis gives additional informations on the bond, as detailed in the legend of Figure 7. The density of energy along the Fe-O path is negative at the bond critical point ( $H_{\mathrm{BCP}}=-0.010$ a.u.) indicates binding, while the positive charge density Laplacian signals a minimum of charge at this point sign of an ionic or a noncovalent bond ${ }^{25} 26$. Both values of $\rho_{\mathrm{BCP}}=$ 0.043 a.u. and $\nabla^{2} \rho_{\mathrm{BCP}}(0.14$ a.u. $)$ are significant, compared with the similar values for strong $\mathrm{Zn}-$ (bipyridyl) 2 complexes ${ }^{34}$. This analysis confirms a Fe-O non-covalent bond of a certain importance, in agreement with the sharing of the oxygen $\pi$ lone pair with the Fe $\left(3 d_{z 2}\right)$ orbital.

\section{5-2 Spectra and excited states of ferric heme adducts}

The comparison of calculated electronic spectra with experiment yields also interesting informations on the structure of ligated ferric heme. Both free and water complexed heme spectra have been calculated in the $300-1000 \mathrm{~nm}$ region. Gouterman et al. ${ }^{35}$ described first the electronic structure of porphyrins in a simple $4 \pi$ electron model, that still accounts for the major features of the porphyrin spectra. There are transitions specific to the porphyrin cycle describing the Soret and Q bands but also transitions labeled as charge transfer, since they involve an electron transfer between the porphyrin and the metal ${ }^{36}$, through electronic excitation. In a porphyrin to metal charge transfer transition, an electron will populate an orbital of the metal (if free ) involved in the 
ligation. This should be in principle another sensitive probe of the electronic properties of the metal water ligation.

Comparing the calculated spectra of free, $\mathrm{N}_{2}$ complexed and water complexed PP-Fe ${ }^{\mathrm{III}}$ (direct and convoluted with a width of $40 \mathrm{~nm}$ ) in Figure S3A of ESI, it appears that they bear a close resemblance in wavelength regions 300-600 nm, the domain of known porphyrin bands (Soret 370 and Q 500-560 nm) with the expected intensity ratios. This resemblance is confirmed in the analysis of the ground and excited wave functions, which in these regions bear a major weight over porphyrin $\pi$ orbitals. A more detailed account of the wave functions of ligated and free heme is given in Tables $\mathrm{S} 3$ of ESI.

a)

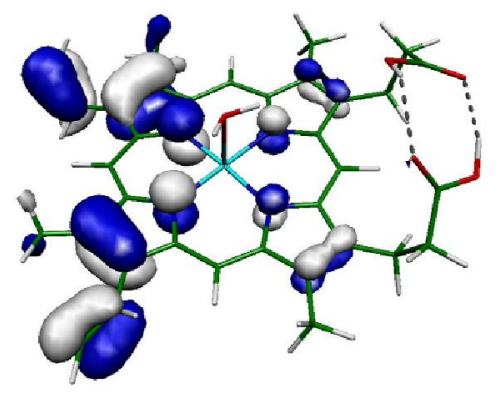

b)

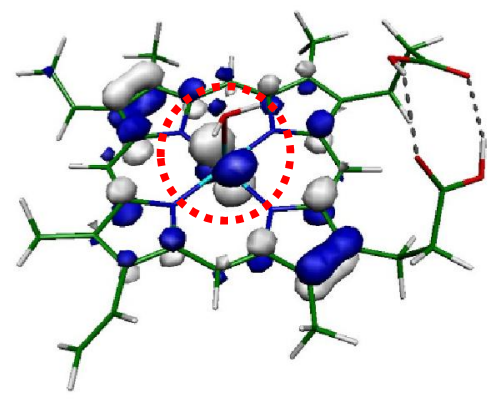

Figure 8- Kohn-Sham molecular orbitals involved in the $622.17 \mathrm{~nm}$ transition of $\left[\mathrm{PP}-\mathrm{Fe}^{\mathrm{III}}-\mathrm{H}_{2} \mathrm{O}\right]^{+}(61 \%$ contribution). $a$, and $b$ represent respectively the HOMO-2( $\beta)$ and $L U M O+1(\beta)$ as the orbitals contributing most to single electron transitions. HOMO and LUMO stand for the highest occupied and lowest unoccupied single electron MO's respectively. The metal $d_{\pi}$ contribution in panel $b$ of the excited state, has been shown by a circle.

In difference, contributions of excited orbitals centered on the Fe atom become most important after $600 \mathrm{~nm}$, as shown in Figure 8, where the $622.17 \mathrm{~nm}$ transition of the water complex displayed in Figure 5a shows a dominant porphyrin to metal charge transfer contribution by the population of a $\mathrm{d} \pi$ orbital shown in Figure $8 \mathrm{~b}$. Besides this bands shifts to 680 and $690 \mathrm{~nm}$ respectively in the calculated spectra of the $\left[\mathrm{PP}-\mathrm{Fe}^{\mathrm{III}}-\mathrm{N}_{2}\right]^{+}$complex and $\left[\mathrm{PP}-\mathrm{Fe}^{\mathrm{IIII}}\right]^{+}$(shown at 683.29 in table S3B of ESI).

In Figure 5a, there is a good agreement between the calculated spectrum (blue sticks) and the experimental spectrum confirming our modelling of the $\left[\mathrm{PP}-\mathrm{Fe}^{\mathrm{III}}-\mathrm{H}_{2} \mathrm{O}\right]^{+}$complex. Thus we can, in 
view of the convoluted spectrum of figure S3A of ESI, assign the experimental $617 \mathrm{~nm}$ band as a porphyrin-metal $(3 \mathrm{~d} \pi)$ charge transfer band of the $\left[\mathrm{PP}-\mathrm{Fe}^{\mathrm{III}}-\mathrm{H}_{2} \mathrm{O}\right]^{+}$complex.

\section{5-3 Binding energies of the complexes}

The binding energy of $\mathrm{H}_{2} \mathrm{O}$ with $\left[\mathrm{PP}-\mathrm{Fe}^{\mathrm{III}}\right]^{+}$is important, since in our low partial pressure conditions, we observe the onset of the equilibrium already at $280 \mathrm{~K}$ between complexed and free heme; this is a simple experimental evidence of a 'strong' ligation. The resulting measured binding energy amounts to $-12.2 \mathrm{kcal}^{\mathrm{mol}}{ }^{-1}$, which is well reproduced within the present calculations, -11.7 kcal.mol ${ }^{-1}$ (Table 1, OPBE) on the ferric heme system. The attachment of a second water ligand in the $6^{\text {th }}$ axial position yields a weaker bond for the second $\mathrm{H}_{2} \mathrm{O},-9 \mathrm{kcal} \cdot \mathrm{mol}^{-1}$, also well reproduced by the calculations, $-7.1 \mathrm{kcal}^{\mathrm{mol}}{ }^{-1}$. The second water molecule is fixed in the 6th coordination position of [PP-Fe $\left.\mathrm{Fe}^{\mathrm{III}}-\left(\mathrm{H}_{2} \mathrm{O}\right)_{2}\right]^{+}$and not to the other water molecule. This stems from the lower binding energy of the free water dimer, only $-3.2 \mathrm{kcal}^{\mathrm{mol}}{ }^{-1}{ }^{137}$, compared to the present $-9 \mathrm{kcal}^{\mathrm{mol}} \mathrm{m}^{-1}$ for sixth coordination with $\mathrm{Fe}-\mathrm{O}$ binding.

Thus, in the axial coordination the two $\sigma$ bonds counteract each other, but in a much less intense way as compared with the $\sigma$ donor MI. Indeed, experimentally, binding to MI in $5^{\text {th }}$ coordination allows in our water concentration conditions, a weak attachment of water in $6^{\text {th }}$ position that places its energy above $-7 \mathrm{kcal}^{\mathrm{mol}}{ }^{-1}$. Calculations show also a reduced energy for this $6^{\text {th }}$ coordinated complex, $-7.4 \mathrm{kcal}^{\mathrm{mol}}{ }^{-1}$ as compared with $-11.7 \mathrm{kcal}^{\mathrm{mol}}{ }^{-1}$ for the 5 th coordinated water complex. Therefore water as $\sigma$ donor in $5^{\text {th }}$ coordination competes far less strongly for the $\mathrm{Fe}\left(3 \mathrm{~d}_{\mathrm{z}}{ }^{2}\right)$ orbital than methylimidazole ${ }^{38}$, but has still a destabilizing effect upon the $6^{\text {th }}$ coordination.

The first ligation of an $\mathrm{H}_{2} \mathrm{O}$ molecule to ferric heme appears as a moderately strong non covalent bond involving a $\sigma$ donation to the $\mathrm{Fe}$ atom.

\section{5-4 The specific character of water bonding to ferric hemes}

Small ligands $\mathrm{CO}, \mathrm{O}_{2}, \mathrm{NO}$, experience a dramatic reduction in their binding properties with $\mathrm{Fe}$ hemes when switching from $\mathrm{Fe}^{\mathrm{II}}$ to $\mathrm{Fe}^{\mathrm{III}}$. The bonding in ferrous $\mathrm{Fe}^{\mathrm{II}}$ hemes is linked to the strong donation to $\mathrm{Fe}\left(3 \mathrm{~d}_{\mathrm{z} 2}\right)$, consequence of a the spin change in the $\mathrm{Fe}^{\mathrm{II}}$ atom that places electrons in the 
$\mathrm{S}=0$ spin state and in the lowest energy $\mathrm{Fe}\left(3 \mathrm{~d}_{\mathrm{z} 2}\right)$ orbitals. On the contrary, $\mathrm{Fe}^{\mathrm{III}}$ hemes have a weaker bonding due to the absence of spin crossing to the low spin $S=1 / 2$ states This lower binding is associated to the presence of a half-filled $\mathrm{Fe}\left(3 \mathrm{~d}_{\mathrm{z} 2}\right)$ orbital. The case of the ligation of $\left[\mathrm{PP}-\mathrm{Fe}^{\mathrm{III}}\right]^{+}$ with $\mathrm{H}_{2} \mathrm{O}$ is shown here as different experimentally, where the ferric $\left[\mathrm{PP}-\mathrm{Fe}^{\mathrm{III}} \mathrm{H}_{2} \mathrm{O}\right]^{+}$is much more strongly bound than the protonated heme $\left[\mathrm{H} \mathrm{PP}-\mathrm{Fe} \mathrm{H}_{2} \mathrm{O}\right]^{+}$, partially ferrous. The bond energy is low, $>-3.1 \mathrm{kcal}^{\mathrm{mol}}{ }^{-1}$ difficult to attain experimentally at temperatures above $170 \mathrm{~K}$, where water is in sufficient concentration. On the theoretical side, the same tendency to a decreased bonding by protonation is observed and examining the binding details in Table 1, one sees that in absence of dispersion (generated mostly by the heme), the bond is repulsive for [H PP-Fe- $\left.\mathrm{H}_{2} \mathrm{O}\right]^{+}$. Calculations on ferrous porphyrins by Strickland ${ }^{39}$ et al. at the CCSD level also found a binding energy close to zero between [Fe ${ }^{\mathrm{II}} \mathrm{P}$ ] (singlet ) and $\mathrm{H}_{2} \mathrm{O}$. We can therefore infer that $\mathrm{H}_{2} \mathrm{O}$, in difference with small ligands $\mathrm{O}_{2} \mathrm{CO} \mathrm{NO}$ does not succeed in inducing a low spin configuration for $\left[\mathrm{PP}-\mathrm{Fe}^{\mathrm{II}}-\mathrm{H}_{2} \mathrm{O}\right]$ and thus ferrous heme is disfavored with respect to ferric heme in its complexation with water, as summarized in $\Delta E c$ and $\Delta E$ within Table 1. The small energy of protonated and ferrous heme water complexes accords also with the absence of direct interference of $\mathrm{H}_{2} \mathrm{O}$ with ferrous hemoproteins, whose complexes only form at low temperatures, in difference with the ferric ones ${ }^{40}$.

\section{6- Conclusions}

The binding of isolated ferric heme with $\mathrm{H}_{2} \mathrm{O}$ has been determined with precision in the gas phase by thermodynamic measurements in a controlled variable temperature ion trap. The van't Hoff method has been chosen to derive the enthalpy of ligation from the measurements of the ratio of ligated heme to unligated heme as a function of temperature. In our setup, at low ligand pressures $10^{-6}$ mbar, equal concentrations of ligated vs unligated heme are observed at $255 \mathrm{~K}$ that corresponds to a deep well. The extrapolated binding energy at $0 \mathrm{~K}$ is $-12.2 \pm 0.6 \mathrm{kcalmol}^{-1}$. This binding energy is important and is several times higher than that of $\mathrm{O}_{2}$ and $\mathrm{CO}$ to ferric heme, however inferior to that of NO $\left(-24.9 \mathrm{kcal}^{\mathrm{m} \mathrm{mol}^{-1}}\right)^{5}$. Therefore, in normal conditions, ferric heme shall not bind $\mathrm{O}_{2}$ nor $\mathrm{CO}$, but easily $\mathrm{H}_{2} \mathrm{O}$. The setup has allowed to explore sequentially the formation of more complex bonds such as the six coordinated $\left[\mathrm{PP}-\mathrm{Fe}^{\mathrm{III}}-\left(\mathrm{H}_{2} \mathrm{O}\right)_{2}\right]^{+}$or $\left[\mathrm{MI}-h e m e-\mathrm{Fe}^{\mathrm{III}}-\mathrm{H}_{2} \mathrm{O}\right]^{+}$. In addition, we 
studied the complexation of protonated ferric heme $\left[\mathrm{H} \mathrm{PP}-\mathrm{Fe}^{\mathrm{II} / I I}\right]^{+}$which was only very weakly observed, while in the same conditions $\left[\mathrm{PP}-\mathrm{Fe}^{\mathrm{III}}-\mathrm{H}_{2} \mathrm{O}\right]^{+}$was easily formed.

The binding characteristics of ferric heme and $\mathrm{H}_{2} \mathrm{O}$ has been investigated through high level DFT calculations with the OPBE functional and the quartet $(\mathrm{S}=3 / 2)$ spin state has been predicted as the most stable spin state for $\left[\mathrm{PP}-\mathrm{Fe}^{\mathrm{III}}-\mathrm{H}_{2} \mathrm{O}\right]^{+}$as for its unligated $\left[\mathrm{PP}-\mathrm{Fe}^{\mathrm{III}}\right]^{+}$homologue. Thus no spin crossing is observed to occur following water ligation to $\left[\mathrm{PP}-\mathrm{Fe}^{\mathrm{III}}\right]^{+}$. The OPBE calculations reproduce the observed binding energy with an energy of $-11.7 \mathrm{kcal}^{\mathrm{mol}}{ }^{-1}$ and confirm a strong interaction. The influence of double ligation in a sixth coordinated complex $\left[\mathrm{Fe}^{\mathrm{III}} \mathrm{TPP}-\left(\mathrm{H}_{2} \mathrm{O}\right)_{2}\right]^{+}$is also well reproduced in calculations, where the second ligation of $\mathrm{H}_{2} \mathrm{O}$ is $20 \%$ weaker than the first.

Nevertheless, spin density calculations show a majority of 3 unpaired electrons on the $\mathrm{Fe}^{\mathrm{III}}$ center, the same as for a free ferric heme in the intermediate spin 3/2. This indicates a non covalent interaction of $\mathrm{H}_{2} \mathrm{O}$ with the $\mathrm{Fe}$ atom in the heme, also characterized in the QTAIM analysis.

The interesting fact is the strong binding energy of $\mathrm{H}_{2} \mathrm{O}$ to $\left[\mathrm{PP}-\mathrm{Fe}^{\mathrm{II}}\right]^{+}$, much higher than measured for small ligands $\mathrm{O}_{2}, \mathrm{CO}$ but smaller than $\mathrm{NO}$ that undergoes an electronically complex binding scheme involving spin crossing to $\mathrm{S}=0$. Here the spin state of the $\left[\mathrm{PP}-\mathrm{Fe}^{\mathrm{III}} \mathrm{H}_{2} \mathrm{O}\right]^{+}$complex remains intermediate as for free ferric heme ${ }^{27}$, even with the ligation occurring through a $\sigma$ donation from the lone pairs to $\mathrm{Fe}\left(3 \mathrm{dz}^{2}\right)$. Therefore water ferric heme occupies a striking intermediate case as Zerner $^{36}$ noted as early as 1966 . This value is even more striking when compared with that of protonated heme ${ }^{13}$ intermediate between ferric and ferrous-heme showing experimentally a considerably diminished binding energy with water. Theoretical calculations lead us to the conclusion that $\mathrm{H}_{2} \mathrm{O}$ does not allow spin crossing in protonated heme or ferrous heme, the source of strong binding. It will be essential now to investigate ferrous heme binding with $\mathrm{H}_{2} \mathrm{O}$, likely via negative ion porphyrins ${ }^{6}$ using the present methods.

In the present investigation of the $5^{\text {th }}$ and $6^{\text {th }}$ coordination of water complexes, the latter coordination indicates a reduction of the $\mathrm{H}_{2} \mathrm{O}$ ligand binding through the trans-axial effect ${ }^{38}$, while water binds met-myoglobin. This $\mathrm{H}_{2} \mathrm{O}$ affinity for the ferric heme protein containing histidine residues has been related with hydrogen bonding of $\mathrm{H}_{2} \mathrm{O}$ with the distal histidine in crystallographic 
measurements ${ }^{1}$. In our stepwise approach of ferric heme binding with ligands, the next experiment will bring a mimic of the presence of distal histidine in order to describe the interaction of iron with water in a hemoprotein pocket.

\section{Acknowledgments:}

This work was supported by the Center for International Scientific Studies and Collaboration (CISSC), French Embassy in Iran and the PHC Gundishapur 2016-2017 project n ${ }^{\circ} 35629$ XE RO and MA, thank the Iranian National Science Foundation (INSF, No. 97018759) and University of Isfahan for support. We are grateful to Laboratoire de Chimie Physique of CNRS and the University of Paris-Sud for supporting our computations. We thank GENCI for a generous time allocation on the CINES supercomputers (project number hcp6830)

\section{References}

1. M. L. Quillin, R. M. Arduini, J. S. Olson and G. N. Phillips, J. Mol. Biol., 1993, 234, 140.

2. W. X. Cao, J. F. Christian, P. M. Champion, F. Rosca and J. T. Sage, Biochemistry, 2001, 40, 5728.

3. R. C. Dunbar and T. B. McMahon, Science, 1998, 279, 194.

4. L. Ferrand, S. Soorkia, G. Gregoire, M. Broquier, B. Soep and N. Shafizadeh, PCCP, 2015, 17, 25693.

5. B. Chiavarino, M. E. Crestoni, S. Fornarini and C. Rovira, Inorg. Chem., 2008, 47, 7792.

6. T. Karpuschkin, M. M. Kappes and O. Hampe, Angew. Chem. Int. Ed., 2013, 52, 10374.

7. S. Dillinger, J. Lang and G. Niedner-Schatteburg, J. Phys. Chem. A, 2017, 121, 7191.

8. D. R. Evans and C. A. Reed, J. Am. Chem. Soc., 2000, 122, 4660.

9. J. Vojtěchovský, K. Chu, J. Berendzen, R. M. Sweet and I. Schlichting, Biophys. J., 1999, 77, 2153.

10. A. Abdurahman and T. Renger, J. Phys. Chem. A., 2009, 113, 9202.

11. M. C. Durrant, Dalton Transactions, 2014, 43, 9754.

12. G. Feraud, M. Broquier, C. Dedonder-Lardeux, G. Gregoire, S. Soorkia and C. Jouvet, PCCP, 2014, 16, 5250.

13. N. Shafizadeh, S. Soorkia, G. Grégoire, M. Broquier, M.-E. Crestoni and B. Soep, Chemistry - A European Journal, 2017, 23, 13493. 
14. B. Chiavarino, M. E. Crestoni, S. Fornarini and C. Rovira, Chemistry-a European Journal, 2007, 13, 776.

15. D. M. Murphy and T. Koop, Quarterly Journal of the Royal Meteorological Society, 2006, 131, 1539.

16. A. M. Koster, G. Geudtner, A. Alvarez-Ibarra, P. Calaminici, M. E. Casida, J. CarmonaEspindola, V. D. Dominguez, R. Flores-Moreno, G. U. Gamboa, A. Goursot, T. Heine, A. Ipatov, A. de la Lande, F. Janetzko, J. M. del Campo, D. Mejia-Rodriguez, J. U. Reveles, J. Vasquez-Perez, A. Vela, B. Zuniga-Gutierrez and D. R. Salahub, The deMon Developers, Cinvestav, México City, 2016.

17. S. Grimme, S. Ehrlich and L. Goerigk, J. Comput. Chem., 2011, 32, 1456.

18. J. M. Wittbrodt and H. B. Schlegel, J. Chem. Phys., 1996, 105, 6574.

19. R. F. W. Bader, Atoms in Molecules, A Quantum Theory, Oxford University Press, New York, 1990.

20. A. D. Becke and K. E. Edgecombe, J.Chem.Phys., 1990, 92, 5397.

21. K. AIMAll (Version 10.05.04), T. A., 2010 (aim.tkgristmill.com).

22. S. Noury, X. Krokidis, F. Fuster and B. Silvi, Comput. Chem., 1999, 23, 597.

23. P. Bultinck, C. Van Alsenoy, P. W. Ayers and R. Carbo-Dorca, J. Chem. Phys., 2007, $126,144111$.

24. R. Ahlrichs, M. Bar, H. Baron, R. Bauernschmitt, S. Bocker, M. Ehrig, K. Eichkorn, S. Elliot, F. Furche and F. Haase, TURBOMOLE V6. 3 2011, a development of University of Karlsruhe and Forschungszentrum Karlsruhe GmbH, 1989-2007, TURBOMOLE GmbH, since 2007, 2011.

25. S. J. Grabowski, Chem. Rev., 2011, 111, 2597.

26. E. Espinosa, I. Alkorta, J. Elguero and E. Molins, J.Chem.Phys., 2002, 117, 5529.

27. M. Aarabi, R. Omidyan, S. Soorkia, G. Grégoire, M. Broquier, M.-E. Crestoni, A. de la Lande, B. Soep and N. Shafizadeh, PCCP, 2019, 21, 1750.

28. B. Chiavarino, M. E. Crestoni and S. Fornarini, Croat. Chem. Acta, 2014, 87, 307.

29. M. A. Duncan, Int. Rev. Phys. Chem., 2003, 22, 407.

30. M. Fang, S. R. Wilson and K. S. Suslick, J. Am. Chem. Soc., 2008, 130, 1134.

31. W. J. Bowen, J. Biol. Chem., 1949, 179, 235.

32. G. N. Lewis, Valence and the structure of atoms and molecules, ACS Chemical Catalog Company, New York, NY USA, 1923.

33. T. Yoshimura and T. Ozaki, Bull. Chem. Soc. Jpn., 1979, 52, 2268.

34. I. Cukrowski, J. H. de Lange and M. Mitoraj, J. Phys. Chem. A., 2014, 118, 623.

35. M. Gouterman, G. H. Wagnière and L. C. Snyder, J. Mol. Spectrosc., 1963, 11, 108.

36. M. Zerner, M. Gouterman and H. Kobayashi, Theor. Chim. Acta, 1966, 6, 363. 
37. B. E. Rocher-Casterline, L. C. Ch'ng, A. K. Mollner and H. Reisler, J.Chem.Phys., 2011, 134, 211101.

38. A. P. Hunt and N. Lehnert, Acc. Chem. Res., 2015, 48, 2117.

39. N. Strickland and J. N. Harvey, J.Phys.Chem. B, 2007, 111, 841.

40. D. C. Lamb, A. Ostermann, V. E. Prusakov and F. G. Parak, European Biophysics Journal, 1998, 27, 113. 